\title{
Genesis and geometry of tilted blocks \\ in the Theban Hills, near Luxor (Upper Egypt)
}

by

Christian Dupuis $^{(1)}$, Marie-Pierre Aubry ${ }^{(2)}$, Chris King ${ }^{(3)}$, Robert W. O’B. Knox ${ }^{(4)}$, William A. Berggren $^{(2,5)}$, Wael Fathi Galal ${ }^{(6)}$, and Marc Roche ${ }^{(7)}$

\section{Prepared for: Journal of African Earth Sciences}

Contact author: Marie-Pierre Aubry: aubry@,rci.rutgers.edu

Key words: Gravitational collapse structures, listric and reverse faults, Pleistocene pluvials, Pleistocene erosion, Tilted blocks 


\section{Genesis and geometry of tilted blocks in the Theban Hills, near Luxor (Upper Egypt)}

by

Christian Dupuis $^{(1)}$, Marie-Pierre Aubry ${ }^{(2)}$, Chris King ${ }^{(3)}$, Robert W. O’B. Knox ${ }^{(4)}$, William A. Berggren ${ }^{(2,}$ ${ }^{5)}$, Mostafa Youssef ${ }^{(6)}$, Wael Fathi Galal ${ }^{(6)}$, and Marc Roche ${ }^{(7)}$

(1) Fundamental and Applied Geology, UMons, Wallonie-Brussels Academy, rue de Houdain, 9, 7000 Mons, Belgium, Christian.Dupuis@fpms.ac.be

(2) Department of Geology, Rutgers University, Busch Campus, Wright Laboratory, 610 Taylor Road, Piscataway, NJ 08853, aubry@rci.rutgers.edu

(3) 16A Park Rd., Bridport DT6 5DA UK, chrking@globalnet.co.uk

${ }^{(4)}$ British Geological Survey, Nottingham, UK, Robert Knox < rwok@btinternet.com>

(5) Department of Geology and Geophysics, Woods Hole Oceanographic Institution, Woods Hole, MA 02543, wberggren@,whoi.edu

${ }^{(6)}$ Department of Geological Sciences, University of Assiut, Assiut, Egypt

${ }^{(7)}$ Ministère des Affaires Economiques, Administration de la Qualité et de Sécurité, NG III Bureau 3.043 Avenue Albert II,16, B-1000 Bruxelles, Belgium, Marc.Roche@mineco.fgov.b

Contact author: Marie-Pierre Aubry: aubry@,rci.rutgers.edu 7324450822 (2044)

\section{Abstract.}

The desertic Theban hills between the edge of the alluvial plain of the Nile and the prominent cliffs at the eastern edge of the Theban Plateau consist of imbricated tilted blocks organized in parallel groups representing successive generations of gravitational collapse structures (or slumps). The older (distal) generations correspond to low, rounded hills farther from the Theban cliffs. The youngest (proximal) generation forms higher hills with young relief. Reverse faults occur at the contact between proximal and distal tilted blocks whereas the proximal tilted blocks rest along listric faults on the substratum (Tarawan Chalk and Esna Shale Formations) and against the Theban cliffs. We hypothesize that the emplacements of the tilted blocks were related to major Pleistocene pluvial episodes, each marked by active flow of the Nile River and significant recess of the Theban cliffs. Tectonic thinning and intensive erosion of the Esna Shale Formation were determinant in shaping the Theban landscape. 


\section{I- Introduction}

The Theban Mountain on the West Bank of the Nile, opposite the town of Luxor, is among the most famous historical sites of the world (Fig. 1). The pharaohs of the $18^{\text {th }}$ through $20^{\text {th }}$ Dynasty $(\sim 1539-$ $1079 \mathrm{BCE}$ ) were buried there, as well as their queens, royal children, high-ranking officials (e.g., royal scribes, governors, viziers, priests, army generals, singers of Amon) and the workers (of the village of Deir El Medina) who served them. Over 700 tombs, many of great beauty, have been excavated in the mountainside. The site of Thebes, at the edge of the Western Desert (i.e., eastern part of the Sahara Desert), was ideally suited for the implementation of religious beliefs and the realization of political ambitions of the time. Overlooked by the dominant pyramidal summit of El Qurn, recessed valleys provided secluded sites for the excavation of tombs and tomb chapels, while a narrow strip of flat alluvial plain was ideally suited to the construction of mortuary temples using the excellent local building stones. At first sight, the geology of the area appears simple, with horizontally bedded Paleogene limestones forming a steep cliff on the edge of the Libyan Plateau and Pleistocene conglomerates occupying valleys and extending from the foot of the cliff towards the alluvial plain of the River Nile. On closer inspection, however, it is apparent that the base of the cliff is fronted by a line of low hills (here referred to as the Theban hills) that represent the eroded tops of major rotational landslips (Curtis, 1979; Cobbold, 2008; Aubry et al., 2009a; Fig. 2). These features are particularly well developed between the amphitheater of El Deir el Bahari to the NE and the Valley of the Queens to the SW, which is the focus of this paper. The aims of our study are to describe the geology of individual hills in order to reconstitute their stratigraphic relationships and establish their internal structure, to establish the nature and timing of the landslide processes, and to assess the vulnerability of the Theban hills and their archeological content to climatic change.

\section{II- Location and geography of the study area}

This geological study of the Theban Mountain is concerned with the sedimentary deposits lying at the eastern edge of the Theban Plateau, forming the hills at the foot of the rugged (sub)vertical cliffs that dominate the landscape (Figs. 1, 2). These hills slope gently towards the flat floodplain of the Nile River. The line of demarcation between hills and plain is sharp, gently curving between the Temple of Medinet Habu to the southwest and the Temple of Seti I to the northeast. Some of the hills (e.g., those of the El Asasif) are composed of in situ Upper Paleocene Tarawan Chalk overlain by Upper Paleocene-Lower Eocene Esna Shale; others are composed of blocks of Lower Eocene Thebes Limestone Formation that 
$2 / 16 / 11$

became detached from the Theban Plateau and tilted while sliding on an incompetent lithology (primarily the Esna Shale) (Aubry et al., 2009a).

The eastern edge of the hills is marked by a succession of recesses and lobes. Three deep valleys oriented NW-SE run roughly perpendicular to the cliffs, delineating three groups of hills (Fig. 2). They are, from north to south: 1) the Valley of El Deir el Bahari, at the rear of which the Temple of Hatshepsut is located, 2) the Valley of Colors, and 3) the Wadi el-Melikat. In addition, the deep and narrow Valley of Deir el Medina, oriented NE-SW, converges towards Wadi el-Melikat. The Valley of Deir el Medina separates the Hills of Qurnet Mura'î from those of Meretseger (see Aubry et al., 2011), and, deeper at the head of the valley, from those of Deir el Medina. The Valley of Colors separates the hills of Qurnet Mura'î and Deir el Medina from those of Sheikh Abd el Qurna (to the NE). Finally, two shallow depressions further divide the hills into individual groups. To the west, a roughly NNW-SSE broad depression separates the Hill of Sheikh Abd el Qurna from that of El Khokhah. To the south, an E-W oriented narrow depression, the Valley of the Dolmen, separates the low hills of Meretseger from the Hills of Deir el Medina, and from those of Deir el Rami (named herein from the Coptic Monastery located there; Capuani et al., 2002).

Although when seen from a distance, the Theban Plateau appears to terminate in a single steep cliff, it is in fact strongly stepped, with five smaller cliffs offset by gently sloping benches of varying degrees of recess (Fig. 3a). The basal cliff (Cliff 1) is developed in the distinctive, markedly fractured, chalky limestone at the base of the Thebes Limestone Formation and forms vertical faces over $90 \mathrm{~m}$ high in places. Unlike the overlying cliffs, Cliff 1 has an undulating top surface and is discontinuously visible (Fig. 2). It towers above the Valley of El Deir el Bahari and Valley of Colors over a length of $\sim 1000 \mathrm{~m}$. It locally forms three small amphitheatres ( $>600 \mathrm{~m}$ long) between the Hills of Deir el Medina and Deir el Rami dominating the Valley of the Three Wells and the Valley of the Cord. It also overlooks the easternmost tributaries of Wadi Bariya (Fig. 1), beyond the Valley of the Queens. It is locally concealed, either by large fans of consolidated and unconsolidated slope breccias and screes (e.g., just north of the hills of el Deir el Medina; Fig. 3b) or by tilted blocks that lie against them (Fig. 3c). North of the Valley of El Deir el Bahari, the cliff front curves gently in a NW-SE direction, and the (eroded) Thebes Limestone Formation is replaced by the detrital deposits of the Hills of Dira Abu El Naga in the Northern Basin (Aubry et al., 2009a).

The overlying four cliffs (Cliffs 2-5 of Figure 3a) are composed of differing types of massive limestone. Cliff 2 is composed of massive chalky limestone not unlike that of Cliff 1, whereas Cliff 3 and 
$2 / 16 / 11$

Cliff 4 are composed of nodular limestone and Cliff 5 is composed of bioclastic limestone. The intervening recessed benches are composed of shale (below Cliff 2) or thinly bedded, commonly argillaceous limestone (below Cliffs 3, 4, 5).

As geographically delineated, the area we have studied extends $\sim 2.5 \mathrm{~km}$ on both sides of an $\sim 2$ $\mathrm{km}$ SW-NE axis centered over a line joining the northeastern wall of the Temple of Thutmosis IV and the entrance to the Valley of Colors (Fig. 2). Elevation varies from a maximum of $\sim 250 \mathrm{~m}$ (at the top of VQ) to a minimum of $\sim 84 \mathrm{~m}$ (Mortuary Temple of Thutmosis III ).

\section{III- Methodology}

This study is an outcome of the field-mapping project of the Theban International Geological Project (TIGA; Aubry et al., 2009a), which has as its goal the construction of a geological map for the West Bank at Thebes. It is based on the careful analysis of geometrical relationships in a region of sharp contrasts where areas with well-exposed stratigraphies are juxtaposed with areas whose geological features are hidden below thick covers of screes, rubbles and breccias. The primary means of correlation throughout the study area is lithostratigraphy, the lower Eocene succession comprising characteristic lithologies with prominent marker beds identifiable over long distances. This, plus biostratigraphy and geomorphologic analysis, have provided the basis for the geological map presented here.

At this time, we refrain from mapping the post-Eocene detrital deposits although these are extensively distributed over the Theban hills. This requires a geomorphologic study that is beyond the scope of this paper. Reference can be made to Said $(1981,1990)$. We make one exception, however. Indurated coarse breccias (in which tombs have been cut) outcrop on the northwest face of the proximal Theban hills forming a band along the Theban cliffs. We formally introduce the name Valley of Colors Formation because they are thickest and well exposed on both sides of that valley (Appendix 1). We refer to all other breccias, screes, conglomerates, whether indurated or not, as "superficial detrital cover".

\section{III-1. Terminology}

Numerous terms have been used to designate gravitational collapse structures (Hesthammer and Fossen, 1999). The Theban structures described here have been referred to variously as "rotated blocks", "rotational slips", "slipped masses" (among other terms) by previous authors (e.g., Abdallah and Helal, 2010; Cobbold et al., 2008; Curtis, 1979). In this study we refer to these structures by using the objective term of "tilted blocks". Each tilted block is clearly a mass of rock that has detached from the Theban Plateau along a decollement plane and now rests at some distance from it. The bedding may have been 
$2 / 16 / 11$

disturbed when sliding occurred, but stratigraphic integrity is generally preserved in the block, indicating decollement en masse. The Theban tilted blocks are imbricated to form several larger complexes. We do not discuss here the detachment surfaces which are located in the Esna Shale Formation. We follow the terminology and classification of Popescu (2005) regarding the causal mechanisms involved in the emplacement of gravitational collapse structures.

\section{III-2. Chronostratigraphy}

Assignment of the Tarawan Chalk, Esna Shale and Thebes Limestone formations to the Upper Paleocene and Lower Eocene Series follows from the definition of the Global Standard of the Paleocene/Eocene Boundary at the base of the Dababiya Quarry Member of the Esna Shale Formation (Aubry et al., 2007). We use Pliocene and Pleistocene sensu Lourens et al. (2004), the age of the Pliocene/Pleistocene boundary being 1.81 Ma. This is in disagreement with the ratification by the International Union of Geological Scientists of a redefinition of the base of the Pleistocene at the base of the Gelasian Stage with an age of $2.58 \mathrm{Ma}$ (Finney, 2010). This redefinition conflicts with virtually all the published literature on the Pliocene and Pleistocene history of Egypt in which the terms Pleistocene and Quaternary are used interchangeably, the Pliocene/Pleistocene boundary being defined by the base of the Calabrian Stage, in agreement with the rules of chronostratigraphy. Concerned with the stability of two chronostratigraphic concepts that were never questioned since their introduction by Lyell (1833, 1839; see discussions in Berggren, 1998, Aubry et al., 2009b, Van Couvering et al., 2009), we follow the recommendations by Van Couvering (2010) with regard to the flexible use of Pliocene and Pleistocene in scientific publications.

The use of the symbols 'Ma' and 'Myr' to express the two aspects of geological time-i.e., date and duration, respectively follows from Aubry et al. (2009c).

\section{III-3. Lithostratigraphic correlations}

\section{III-3-a. Upper Paleocene-lower Eocene formations}

The bulk of the lithologic correlations in the studied area concern the upper part of the Esna Shale and the Thebes Limestone Formations.

The lithostratigraphic succession through the Esna Shale Formation was formalized in Aubry et al. (2007). A detailed lithostratigraphic succession through the Thebes Limestone Formation was recently established along a reference section measured from the contact between the Abu Had Member of the 
$2 / 16 / 11$

Esna Shale Formation and the base of the Thebes Limestone Formation in the Valley of Colors, immediately to the south of El Deir el Bahari (King et al., unpublished manuscript).

The Abu Had Member is readily distinguished from the lower members of the Esna Shale Formation by the occurrence of limestone stringers in light grey shale (Dupuis et al., 2003). Its contact with the Thebes Limestone Formation is abrupt and is easily delineated throughout Upper Egypt.

The Thebes Limestone Formation is a $\sim 340$ m-thick succession of massive calcareous lithologies with occasional thin, soft, shaly or marly intervals. This succession exhibits an upward shallowing trend, from chalks with high proportions of planktonic foraminifera and a general absence of macrofauna in the lower part, to shelly bioclastic limestones and oyster coquinas at the top. Superimposed on this long-term trend is a cyclic depositional pattern with several stacked medium-scale upwards-shallowing sequences, from homogenous chalks through concretionary indurated chalks to intensely Thalassinoides-burrowed nodular chalks. The smallest-scale sequences are marked by inter-burrowed omission surfaces, and ideally comprise a thin basal bioclastic limestone, followed by homogenous chalks grading up to concretionary indurated chalks. A prominent omission surface at $93.5 \mathrm{~m}$ above the base, overlain by a thin phosphatic limestone, may indicate a significant hiatus. For convenience, we informally divide the Thebes Limestone Formation into five lithologic units (Fig. 4). These units correspond to the five-fold natural breaks in the vertical extent of the cliffs.

For the purpose of mapping, elements of correlation within the Thebes Limestone Formation include 1) typical lithologies such as nodular and oyster beds, and coquina and 2) characteristic lithologic successions. In this respect the five cliff-forming prominent limestone units constitute reliable markers

(Fig. 4). The basal, almost vertical cliff (Cliff 1 of Figure 3a), $93.5 \mathrm{~m}$ high, is well delineated at its base by $\sim 3 \mathrm{~m}$ of fine-grained, sublithographic light tan limestone, and at the top by $\sim 50 \mathrm{~cm}$ of bioturbated limestone with nodules and phosphatic grains (see above). The top of this intensely burrowed limestone forms an often well-exposed, unmistakable "surface structurale". Characteristically this surface is overlain by $\sim 12 \mathrm{~m}$ of purple and gray shales surmounted by $\sim 20 \mathrm{~m}$ of cliff-forming limestone (Cliff 2) with scattered, stratified flints. The limestone interval is divided into three intervals by two 2 to $3 \mathrm{~m}$ thick shales. The lower of these is not always well exposed (because of accumulation of screes at this level), but the upper one, a purple shale, is readily recognized in outcrop, underlined by a thin oyster bed. The top of Cliff 2 forms a prominent feature (Figs. 3a, 4) marked by a shaly calcarenite, $50 \mathrm{~cm}$ to $1 \mathrm{~m}$ thick. Stratified limestone forms a third, $\sim 55 \mathrm{~m}$ high cliff (Cliff 3). The upper $15 \mathrm{~m}$ of this limestone is nodular and underlain by three prominent oyster beds, the middle one double and easily recognized in outcrop. 
The nodular limestone is surmounted by a prominent oyster-rich limestone that marks the top of Cliff 3 . The section between the top of Cliff 3 and the base of Cliff 4 consists in ascending sequence of $1 \mathrm{~m}$ green shale, a $75 \mathrm{~cm}$ thick coquina, $50 \mathrm{~cm}$ purple shale, $5 \mathrm{~m}$ of nodular limestone, and a $\sim 30 \mathrm{~cm}$ yellow shale bed. Above, the cliff consists of laminated limestone with scattered flints. Two characteristic 1 to $1.5 \mathrm{~m}$ thick, cavernous, large flint-bearing beds occur at the top of the fourth cliff. Finally, the fifth cliff, $43 \mathrm{~m}$ thick, is topped by oyster beds.

Lithostratigraphic correlations are remarkably clear on the West Bank. However, calcareous nannofossil biostratigraphy (Martini, 1971; Aubry, 1996) has proved useful in confirming lithostratigraphic assignment of slivers of Esna Shale at the toe of tilted blocks.

\section{III-3-b. Younger deposits}

In the course of mapping the geology of the Theban hills we have been confronted to the problem of systematically individualizing and correlating terrestrial detrital deposits that overlie the much older Paleocene-Eocene marine succession. Some (perhaps all) have been described as the Armant Formation (Said, 1975, 1981) deposited during the early Pleistocene under wet climatic conditions (Armant Pluvial). A $40 \mathrm{~m}$ section of this formation is described in Wadi Bairiya (Fig. 1). It consists of beds of locally derived, subangular and poorly sorted gravels cemented by tuffaceous material, alternating with finegrained, clastic rock. Said (1975) has also described the Issawia Formation "made up of bedded travertines with minor conglomerate lenses with pebbles of local derivation and an overlying bed of red breccia with highly angular limestone pebbles cemented in a matrix of red muds" (Said, 1981, p. 124). The Issawia Formation overlies the Armant Formation in Upper Egypt, but according to Said, it is of lesser extent than the latter.

In the Theban hills, an indurated, detrital deposit consisting of massive breccias, conglomerates and arenites (Fig. 5) occurs continuously atop the lower Eocene Thebes Formation at the western edge of the Hills of Sheikh Abd el Qurna and El Khokhah. It also occurs in the shallow depression between the western and eastern Hills of Qurnet Mura'î (Fig. 6). The size of the boulders in this deposit is much larger $(>1 \mathrm{~m})$ than the maximum size $(50 \mathrm{~cm})$ of the boulders in the Armant Formation in the Barayia section (Said, 1981). It is possible that this deposit represents the Issawia Formation, but it was not individualized as such in Said's map of the Theban Mountain (Fig. 1 herein), and a sedimentologic study is required to ascertain this relationship. We describe it here as the Valley of Colors Formation (appendix 1). As will be shown below, the Valley of Color Formation occurs at fault contacts between tilted blocks. 


\section{III-3. Structures}

Special attention has been given to anomalous structural contacts, such as listric and reverse faults. We describe the contacts between tilted blocks of successive generations as 'reverse faults' because following collisions the strata of the older tilted blocks overlap the strata of the youngest. Because of an extensive superficial detrital cover, access to the contacts between tilted blocks and the substratum on the one hand, and between distal and proximal tilted blocks on the other, are often of limited extent. Tabular structure characterizes the substratum (Tarawan Chalk and Esna Shale Formations) and the Theban Plateau (Thebes Limestone Formation) (Aubry et al., in press, Fig. 3a). For the tilted blocks, faults were mapped and the dip and orientation of strata were measured along selected profiles.

\section{III-4. Topographic and geological maps}

We have used for our fieldwork the detailed topographic map in 20 parts established by Baraize (1904-1913); however, we refer herein to the "Tourist edition" of the topographic map established at 1:10.000 scale by the Geological Survey of Egypt from a 1922 survey. The reason for this substitution is that the latter map was more easily digitized for the purpose of this paper (Fig. 2). The orthography of the names of localities herein is adopted from the map of Baraize. We also refer to K. Weeks (ed., 2001) for the names of valleys in the southwestern hills.

The geological map (Fig. 6) is based on the transfer by one of us (CD) of lithological and structural field observations onto the topographic map with the invaluable aid of Google Earth maps. For the purpose of this paper, the map shows the extent of the units the Thebes Limestone Formation naturally delineated between cliffs, and the distribution of the Esna Shale and Tarawan Chalk Formations in the Theban Hills and the Valley of the Kings. Units 2 and 3 are mapped as a single unit herein, and the four members of the Esna Shale Formation are undifferentiated. Additionally, the mapping of the Northern Basin is in progress; it is not considered herein.

\section{IV- Stratigraphic description of the Tilted Blocks}

Most of the hills at the base of the Theban Mountain correspond to tilted blocks (Curtis, 1979; Yehia et al., 1982; Cobbold et al., 2008; Aubry et al., 2009a, in press). A marked contrast occurs between 1) hills with a rounded top, of which the stratigraphy is often obscured by a thick, almost continuous superficial detrital cover, and 2) hills with a rugged morphology, clearly exhibiting the well-stratified lithostratigraphic succession that characterizes the Theban Plateau but with strata dipping towards the 
$2 / 16 / 11$

northwest. The low, soft-relief hills lie at the edge of the alluvial plain, whereas the sharp-relief hills are located between them and the Theban Plateau. We refer to these two groups of hills as distal and proximal, respectively, in reference to their distance from the Theban front (i.e., the vertical cliff of unit 1). Using geomorphologic and geological characters, we show below that distal and proximal hills also correspond to distal and proximal tilted blocks. In this description, we group the hills so as to reflect the natural organization of the landscape.

\section{IV-1. Hills of Sheikh Abd el Qurna and El Khokhah}

The hills of Sheikh Abd el Qurna and El Khokhah (Figs. 7a, b) form a group aligned northeastsouthwest, essentially parallel to the Theban front and the edge of the flood plain (Fig. 2). A weak and broad depression separates them (Fig. 7b).

\section{IV-1-a. The Hill of El Khokhah}

The small, broadly kidney-shaped, $\sim 110 \mathrm{~m}$ high Hill of El Khokhah is formed by unit 1 of the Thebes Limestone with beds dipping $>60^{\circ}$ to the northwest (Figs. 6, 8). It is overlain in the NE corner by a tongue of the Valley of Colors Formation (Fig. 6). The contact of the displaced strata with the substratum (e.g., in the Hills of El Asasif) is well displayed in outcrops (Fig. 8). Well stratified but fractured dipping strata of unit 1 of the Thebes Limestone Formation are separated from horizontally bedded limestones of the Tarawan Chalk by a veneer of Esna Shale (Hanadi Member) of variable thickness.

\section{IV-1-b. The Hill of Sheikh Abd el Qurna}

This almost circular hill reaches a height of $>170 \mathrm{~m}$ (Figs. 2, 7a). Its southeastern flank is extensively built over but the western flank exhibits a complete lithologic succession through the Thebes Limestone Formation, from unit 1 to at least unit 4 (Fig. 9). As at El Khokhah the beds dip generally $>60^{\circ}$ $\mathrm{NW}$, but with broad variations between 20 and $85^{\circ}$. The contact of the tilted strata with the substratum is well exposed in numerous locations. The Thebes Limestone Formation is separated from the Tarawan Chalk by a thin veneer of Esna Shale (Hanadi Member) (Fig. 10).

On the northwestern flank, a thick package of the Valley of Colors Formation conceals the dipping strata of the Thebes Limestone Formation (Figs. 11a-c). This package abuts the Abu Had Member of the Esna Shale Formation of the substratum along a listric fault (Figs. 11b, c). A 1-m wide interval marked by highly fractured shale with disturbed stratification characterizes the contact. 
The continuity of the outcrops of unit 1 and of the Valley of Colors Formation indicates that the hills of Sheikh Abd el Qurna and El Khokhah belong to the same tilted block. Similar anomalous contacts between the Tarawan Chalk and unit 1 occur in the shallow depression between the two hills (Fig. 12).

\section{IV-2. Hills of Deir el Medina, Qurnet Mura'î and of Meretseger}

Together, the hills of Deir el Medina, Qurnet Mura'î and Meretseger form a promontory along a NW-SE axis delineated to the northeast by the entrance of the Valley of Colors and to the southwest by Wadi el-Melikat. This promontory extends close to the flood plain at the level of the Temple of Merneptah (Fig. 2). Both the hills of Qurnet Mura'î and of Meretseger culminate at $140 \mathrm{~m}$. Those of Deir el Medina are markedly higher $(200 \mathrm{~m})$, forming a spur that ends in a steep cliff.

\section{IV-2-a. The hills of Deir el Medina}

The south-southeast facing cliff (Fig. 13) exhibits $\sim 18 \mathrm{~m}$ of shale of the Abu Had Member of the Esna Shale Formation overlain by the massive limestones of unit 1 of the Thebes Limestone Formation. A complete succession through the Thebes Limestone Formation up to the lower part of unit 4 constitutes the bulk of the hills (Fig. 14a). This normal lithologic succession dips to the NW with an angle of $45-50^{\circ}$. The higher levels of the Thebes Limestone Formation are concealed in the northwestern part of the hills under the Valley of Colors Formation, which extends eastwards to rest directly on the substratum in the northeast facing flank of the hills (in the Valley of Colors, Fig. 14a). The contact between the formation and the substratum is a listric fault that, in the valley, truncates at low angle the horizontally stratified shale of the Abu Had Member (Figs. 14b, c), and, in the Theban cliffs, curves upwards to form the structural contact between the tilted block and Theban Plateau (Fig. 14a). The anomalous contact between the Theban Plateau and the tilted block of Deir el Medina is mostly under screes over much of its southwest facing flank, except for a few local outcrops (Fig. 15).

\section{IV-2-b. The hills of Qurnet Mura'î}

The two hills of Qurnet Mura'î culminate at $140 \mathrm{~m}$ (Fig. 2). The smaller western hill is comprised of $\sim 30 \mathrm{~m}$ of Esna Shale (El Mahmiya and Abu Had Members) overlain by the lowermost part (4 m) of the Thebes Limestone Formation (Fig. 16a, b). The strata are warped along a ENE-WSW axis and faulted. This western hill is clearly in stratigraphic continuity with the hills of Deir el Medina, and it is part of the same tilted block (proximal tilted block of Deir el Medina) (Fig. 13).

Thick, indurated screes cover the eastern hill, largely concealing its stratigraphy, although the Valley of Colors Formation outcrops in the southwest-facing slope. It is a structurally independent tilted 
$2 / 16 / 11$

block against which the proximal tilted block of Deir el Medina abuts along a reverse fault marked by the contact of the Esna Shale Formation with the Valley of Colors Formation. The situation is similar to that in the Hill of Sheikh Abd el Qurna (Figs. 17a, b). The contact between this distal block and the substratum is not known in outcrop. However, the Tarawan Chalk occurs in a tomb in the nearby Valley of Colors, $\sim 5$ m southwest of the northeastern tip of the hill.

\section{IV-2-c. The hills of Meretseger}

The hills of Meretseger form a triangular promontory, with three minor summits, 110, 130 and $140 \mathrm{~m}$ high (Fig. 2). Indurated screes and breccias conceal their geology, and the contact with the substratum is unknown. The ruins of the sanctuary of Ptah and Meretseger furnish a valuable, albeit restricted, glimpse into their stratigraphy and structure. There, highly fractured slabs of the Thebes Limestone Formation are juxtaposed along faults with thick breccias of diverse origins. Evidence, such as the loss of stratification in the limestones and the deformation of once horizontal layers of flints, suggest a long history of deformation, folding and faulting (Aubry et al., 2011).

\section{IV-3. The Hills of Deir el-Rami}

These hills in the Thebes Limestone Formation abut the Theban front (Fig. 4b). The strata dip to the NW at angles of $80^{\circ}$. The contact between the tilted layers of the upper part of unit 1 and the substratum is not visible, but the listric fault between the tilted layers of the upper units and the horizontal layers of unit 1 of the Theban cliff is well exposed.

\section{IV-4. Hills of the Valley of the Queens}

The tombs of the Valley of the Queens were excavated at the base of a massive tilted block (Cobbold et al., 2008; Aubry et al., 2009a) that towers over the Wadi el-Melikat (Fig. 18a). This tilted block is part of a larger geomorphologic unit forming a $100 \mathrm{~m}$ long, trilobate promontory that extends roughly NE-SW over a distance of $\sim 2000 \mathrm{~m}$, facing the flood plain from the Temple of Ramesses III at Medînet Habu (to the north) to beyond the Coptic Orthodox Cemetery (to the South) (Fig. 2). Each lobe of the promontory constitutes a low hill, the northern ones $\sim 200 \mathrm{~m}$ high, the southern one $120 \mathrm{~m}$ high.

\section{IV-4-a. The proximal tilted block}

The rugged northeast-facing flank of the proximal tilted block, familiar to visitors of the tombs, does not account for the geographic extent of the block itself. The latter is broad, with an undulating upper rim that forms two elongate, narrow spurs that project southeast on each side of a broad, $\sim 240 \mathrm{~m}$ high, recessed rounded hill. The eastern spur is $\sim 210 \mathrm{~m}$ high, the western one $\sim 200 \mathrm{~m}$ (Figs. $2,18 \mathrm{~b}$ ). The 
$2 / 16 / 11$

precipitous cliffs that delineate the block afford continuous exposures, bed-by-bed, of the complete lithologic succession up to at least the top of unit 4 of the Thebes Limestone Formation, and readily correlated with strata in the nearby Theban cliffs.

The details of the contact of the proximal tilted block with the Theban front are still under analysis, but a listric fault is easily delineated (Fig. 18b). The contact between the base of the proximal tilted block and the substratum was not found in outcrop. In other words the surface of detachment is not known for this block. The contact between the proximal tilted block and the adjacent distal block is also not precisely located as yet although the warping of the beds of the Abu Had Member and the lowest bed of unit 1 of the Thebes Limestone Formation suggests its proximity to the east (Fig. 19a).

\section{IV-4-b. The distal tilted blocks}

The three gently rounded distal hills that lie beyond the proximal tilted block possess a continuous, 1 to $1.5 \mathrm{~m}$ thick, superficial detrital cover (Figs. 2, 18a, b). These hills may consist of two broad, imbricated tilted blocks, but the stratigraphy of the most distal hills is unknown at this time. The intermediate hills belong to a tilted block that exhibits a complete lithologic succession from the Abu Had Member of the Esna Shale Formation to at least the lower part (purple and gray shales and lower beds of the overlying limestone) of unit 2 of the Thebes Limestone Formation. As elsewhere in the Theban hills, the top of unit 1 of the latter formation forms a prominent, characteristic scarp, with strata dipping $\sim 40^{\circ}$ to the southwest (Fig. 6). The contact between this block and the proximal tilted block is marked by a series of minor faults, unit 2 of the Thebes Limestone Formation of the distal block being in contact with unit 1 of the same formation of the proximal block (Fig. 6). The lithologic repetition is remarkable even though the contact between the two blocks is difficult to locate precisely. An isolated, small, scar-like quarry near the top of the easternmost hill (Fig. 2) reveals the lithologic and structural complexity close to the contact between the two blocks (Fig. 19b). The grey and purple shales and the massive limestone bed at the base of unit 2 of the Thebes Limestone Formation outcrops in the distal block is visible. The lithologic succession is normal but the stratigraphic succession is not. The thicknesses of the marls and shales are considerably reduced compared to a normal succession (tectonic thinning), and the stratification of the shales has been disturbed. A fault runs parallel to the axis of the scar at the contact between units 1 and 2 . Another fault occurs along the base of the massive limestone of unit 2. The top of unit 1 can be followed southwestwards over $\sim 500 \mathrm{~m}$.

\section{V- Discussion}


The tilted blocks (TB) of the Theban hills exhibit a lithostratigraphic unity coupled with a diversity of geomorphological settings and structural complexity. All are blocks of Thebes Limestone Formation (unit 1 to at least unit 4), sometimes in stratigraphic continuity with the Abu Had Member of the Esna Shale Formation (as in the Deir el Medina TB), marked by a strong (predominantly NW, $40^{\circ}$ to $>60^{\circ}$ ) dip towards the Theban cliffs. The relation of the blocks to the present landscape varies between blocks. As noted above, the hills of Sheikh Abd el Qurna and El Khokhah belong to a single proximal TB, as do the the hills of Deir el Medina and the western hill of Qurnet Mura'î; the broader eastern hill of Qurnet Mura'î belongs to a separate distal TB; the hills of the Valley of the Queens represent a complex of one proximal and possibly four distal TBs; the hills of Meretseger and of Deir el-Rami also correspond, respectively, to a distal and proximal $\mathrm{TB}$, the latter much smaller than the other proximal TBs.

Basically, all the hills that lie in front of the Theban cliffs are TBs that became detached from the Theban Plateau. Although no outcrops exhibiting the contact between distal TBs and substratum have been found until now, their lithologic composition and structure are firm evidence of their nature.

In the light of the above descriptions a number of questions arise: How do TBs in the same ensemble of hills relate to one another? How many episodes of slumping were there? When and why did slumping occur? Additionally, what were the consequences of slumping on the landscape?

\section{V-1. Relationships between distal and proximal tilted blocks}

Determination of the relationships between proximal and distal TBs lies in the examination of the contacts between TBs, substratum and eventually Theban front. These contacts cannot be documented for all blocks - for lack of exposures under an extensive superficial detrital cover-but extrapolations can be made from one or several examples.

When exposed, two types of contact occur. One is a listric fault, the other a reverse fault. We have documented the presence of a listric fault:

1) between the substratum and the base of the TB of Sheikh Abd el Qurna-El Khokhah. At the southeast front of this TB, the listric fault brings the displaced unit 1 of the Thebes Limestone Formation into contact with the Tarawan Chalk Formation (Figs. 8, 10), indicating that $>100 \mathrm{~m}$ of Esna shales that normally occur between the two formations have been displaced. At its northeast end, the contact occurs between the displaced Valley of Colors Formation and the Esna Shale Formation of the substratum (Fig. $11 \mathrm{a}-\mathrm{c})$.

2) at the base of the TB of Deir el Medina (Fig. 14a), where the fault truncates the horizontally stratified Esna Shale of the substratum in the valley, and runs upwards towards the Theban cliffs where it 
$2 / 16 / 11$

is visible on both the northwest and southeast flanks of the TB. There, the Valley of Colors Formation leans against the horizontal strata of the Thebes.

3) at the contact between the TB of Deir el Rami and unit 1 in the Theban Cliff; and

4) at the contact between the proximal TB of the Valley of the Queens and unit 1 in the Theban Cliff (Fig. 18b).

Listric faults are characteristic of slumping, that is, the collapse of strata over an incompetent lithology. Deformation (folding and stretching) of strata, fractures, and tectonic thinning of the soft lithologies develop in association with slumping. We have illustrated such features for the TBs of Sheikh Abd el Qurna-El Khokhah and Deir el Medina.

We have documented a reverse fault in the hills of Qurnet Mura'î, between the proximal TB of Deir el Medina and the distal TB of Qurnet Mura'î. This fault is associated with warping of the frontal strata of the proximal TB (Figs. 17a, b). A reverse fault has not been located between the proximal and distal TBs of the Valley of the Queens, but warping of the frontal strata of the proximal tilted block (Fig. 19a) suggests such an occurrence. We have also documented the structural complexity of two distal TBs (easternmost hills in the Valley of the Queens, and Hills of Meretseger [Aubry et al., 2011]), in which the stratigraphic succession of the Thebes Limestone Formation is considerably disrupted.

In sum, listric faults occur at the contact between proximal TBs and the substratum. Reverse faults occur at the contact between distal and proximal blocks.

We interpret the proximal and distal TBs as corresponding to different generations of rotational gravitational collapse. The distal TBs represent one or more older generations. One generation may include the two easternmost TBs of the Valley of the Queens and the Sanctuary of Path TB, aligned along a SW-NE axis parallel to the Theban front. From relief on Goggle Earth Images, we tentatively infer the presence of an older, more distal generation, represented by the two south-westernmost hills of the Valley of the Queens. The TD of Qurnet Mura'î is probably part of the younger generation of distal TBs. It formed when the Theban front was closer to the flood plain, and without obstacle to its migration towards the Nile Valley, as its broad front indicates.

The proximal TBs constitute a younger generation. Sliding over the substratum was limited by the presence of the distal TBs with which they collided, pushing them forwards and causing intense structural deformation. This resulted in the warping of the frontal strata of the proximal TBs, and reverse faulting. For lack of accommodation, the proximal TBs could not slide away from the Theban front. Although detached, they lean against it. The TB of Sheikh Abd el Qurna-El Khokhah is an exception. Without 
$2 / 16 / 11$

distal TB to stop its progress, it moved closer to the flood plain than any of the other proximal TBs and almost as much as the distal TB of Qurnet Mura'î.

\section{V-2. How many episodes of slumping?}

The current landscape in the forehills of the Theban Mountain reflects at least three main episodes of slumping that occurred at distant times, resulting in as many generations of tilted blocks. We do not imply that all TBs of a given generation would have been emplaced simultaneously, but each generation would result from the same combination of preparatory and triggering causal factors acting over a short duration. Preparatory causal factors would be the recession of the Theban front and the erosion of the earlier generation of TBs. Triggering causal factors would be higher seismicity and/or humidity (see below). As discussed above, the two south-westernmost distal TBs of the Valley of the Queens probably represent the earliest generation of TBs. However, we refrain from taking them into consideration in the following discussion because of a lack of data.

The emplacement of the distal TBs was followed by significant erosion, which reduced their morphology into gentle hills, while, simultaneously, causing the Theban front to recess. Further sliding of TBs resting on in situ Esna Shale Formation (the substratum) during this erosive episode may have occurred as well. The current situation of the Sheikh Abd el Qurna-El Khokhah TB (although a proximal TB) constitutes a good model of the geomorphologic conditions just prior to a slumping episode where several generations of TBs occur en echelon. In the absence of obstacle(s) ahead of it, the Sheikh Abd el Qurna-El Khokhah TB spread into a circular mound as it progressed forward on the Esna shales of the substratum until stopped by the Tarawan Chalk; it was subsequently eroded into rounded hills, and the space between it and the cliffs in the Valley of Colors is now sufficiently large to eventually accommodate a TB comparable in size to that of the Valley of the Queens. It is noteworthy that the distal TB of Qurnet Mura' $\hat{\text {, }}$ unimpeded in its eastwards sliding towards the Nile, is of similar shape as the (proximal) Sheikh Abd el Qurna-El Khokhah TB (Fig. 2).

The erosive episode resulted in abundant screes left on the hills, subsequently cemented into a protective superficial detrital cover promoted by drier conditions.

The accumulation of the pebbles, gravels, sands, clays, and other particles that compose the Valley of Colors Formation is clearly related to an erosive, humid episode as well. As the formation is an integral part of the proximal TBs - and not a deposit that formed subsequent to slumping at the contact between TBs and substratum (i. e., not a tectonic breccia) - it must have been deposited on the Theban Plateau, on 
$2 / 16 / 11$

a slope or at the foot of the Theban cliffs (Fig. 20). Cementation of the breccias would have occurred under dry conditions.

The youngest episode of gravitational collapse corresponds to the detachment of the proximal TBs. We attribute the slumping of the Sheikh Abd el Qurna-El Khokhah TB to it as well. This episode was also followed by intensive erosion, resulting in the current system of valleys (e.g., Valley of El Deir el Bahari; Valley of Deir el Medina; Valley of Colors; Wadi el-Melikat). The opening of a window in the Deir el Medina TB through clearance of the lower strata of unit 1 of the Thebes Limestone and the Esna Shale Formations (Fig. 13) is an indication of the magnitude of the erosional power of torrential rainwaters. The amphitheatre of El Deir el Bahari was cleared, and the Hills of El Asasif probably flattened. It is clear that erosion was more intensive in the northeast part of the Theban hills than in the southeast. This is easily explained by the low anticline in the El Asasif area and vicinities, raising up the Tarawan Chalk near or at the surface and simultaneously exposing much of the soft Esna Shale Formation.

\section{V-3. When and why did slumping occur?}

In the current absence of independent means of dating the emplacement of the TBs, the timing of the gravitational collapse(s) may be determined based on documented geological/climatic events that may have affected the local geological history. Taking into consideration the combination of preparatory and triggering causal mechanisms that would optimize conditions for gravitational collapse (see above), some periods were clearly more favorable to slumping than others, particularly during the Pleistocene.

The cutting of a vast canyon by the Eonile 5.5 Ma during the Messinian desiccation of the Mediterranean (Said, 1981, 1990) was a prerequisite to gravitational collapse along the Nile. This produced a prominent escarpment at the eastern edge of the Theban Plateau. The stratigraphic occurrence of the Esna Shale Formation, $\sim>80 \mathrm{~m}$ thick, below a considerable $(\sim 340 \mathrm{~m})$, rigid mass of limestone was another preparatory causal factor to slumping. As early as 1933 (much before the concept of a deep canyon arose), Sandford and Arkell determined that heavy runoff during the cutting of gorges through the Libyan Plateau by the Nile River triggered the detachment of large masses from the limestone cliffs, causing them to slide on the Esna shales. These authors concluded that all slipped masses along the Nile Valley, and in particular around Thebes, formed during the Messinian ("Pontian") pluvial (op. cit., p. 82). The idea of slumping associated with deep cutting of the valley near Thebes was rejuvenated recently (Aubry et al., in press) in the light of findings in laboratory modeling of gravitational collapse processes (Poorvin, 2010). It is possible that the most distal (or easternmost) gravitational collapse structures on the 
$2 / 16 / 11$

West Bank at Thebes were emplaced during the cutting of the Messinian canyon. However, the evidence is clear that not all tilted blocks are linked to this event, the proximal TBs being definitely much younger. Considering the severe erosion to which the West Bank has been exposed during the Pleistocene [Said, 1981; Zaki, 2007], and the recess of the Theban front since the cutting of the canyon, it is possible that slipped masses were at least partly eroded and entombed under younger fluviatile sediments.

A humid climate favored a thick vegetal cover in Upper Egypt during the Pliocene. The mighty Paleonile River transported only fine-grained sediments, mostly clays (Said, 1981). The vegetation would have stabilized the relief, even if rocks were saturated with water. In contrast, climatic change at the beginning of the Pleistocene irremediably changed the landscape of Upper Egypt. Hyper-aridity set in, causing the destruction of the vegetal cover (an additional preparatory causal factor) and intense physical weathering (Said, 1981, 1990, Zaki, 2007). Episodes of intensive rainfall punctuated this new climatic regime, triggering intensive if episodic erosion, massive production of screes, breccias and conglomerates, and sustaining the active flow of an intermittent Nile River (Fig. 21). The two oldest Pleistocene pluvials are represented by the gravels of the Idfu Formation and conglomerates of the Armant Formation, which were laid down by the vigorous Protonile (Said, 1981; 1990). The components of the Armant Formation (particularly well developed in the Theban area) are derived from local source rocks such as Eocene limestones, Paleocene and/or Cretaceous shales, or Nubian sandstones depending on location along the valley (Said, 1981; Zahi, 2007). Two significant younger pluvials (Abbassian I and II) are associated with, respectively, the Prenile river and Neonile river, each characterized by conspicuous conglomerates that underlie (Abbassian I conglomerates) and overlie (Abbassian II conglomerates) the Dendara silts (Said, 1990). Three additional, apparently less intense, pluvials, Saharan I and II and Nabatian, are described by Said (1990).

It would seem reasonable to associate the emplacement of at least some (if not all) tilted blocks of the Theban Hills with Pleistocene pluvials. Considering that they are now low and rounded hills covered with thick indurated screes, the distal TBs are probably ancient. The proximal TBs, much less eroded than the distal TBs, are more recent. We interpreted the Valley of Colors Formation as a breccia that formed on the slopes of the Theban cliffs (see above). Said $(1981,1990)$ described the Issawia Formation as consisting of massive talus breccias resulting from gravity and mass movements during an (inferred?) episode of high seismicity in the valley following an extensive episode of intense aridity. The Issawia Formation immediately overlies the Armant Formation, and underlies the thick, Prenile Qena Formation (Fig. 21). It is possible that the Valley of Colors and Issawia Formations are stratigraphically correlative (see above). Should this be the case, the emplacement of the distal TB of Qurnet Mura'î would postdate 
$2 / 16 / 11$

this deposit (which is involved in the tectonic contact between the distal TB of Deir el Medina and the proximal of Qurnet Mura'î, Fig. 17), being possibly related to the prominent Abyssian I or Abyssian II pluvials. The proximal TBs would then likely be of associated with the Saharan I, Saharan II or Nabatian pluvials.

The youngest pluvials $(<\sim 260 \mathrm{Ka})$ in Egypt are now well dated (Nicholson and Flohn, 1980; Brookes, 1993; Wendorf et al., 1993; Szabo et al., 1995; Crombie et al., 1997; Sultan et al., 1997; Churcher et al., 1999; Hamdan, 2000; Hoelzman et al., 2000; Nicoll, 2001; Smith et al., 2004; Kliendienst et al., 2006; Kieniewicz and Smith, 2007), but uncertainty remains as to the age of the older pluvials. Comparative studies have revealed a synchronous history of rivers around the world (e.g., Bridgland et al., 2007; Bridgland and Westaway, 2008a, b). However, the lower and middle Pleistocene fluviatile record in the Nile Valley in Upper Egypt is discontinuous due to repeated interruptions of the river flow (Said, 1981, 1990, 1993), and the means of stratigraphic correlation are limited by the absence of fossils or human tools. Based on Said (1990, fig. 25.9, table 25.1), and accepting the relative chronology precariously established above, emplacement of some of the Pleistocene distal TBs may be dated to around 0.4 Ma (Abyssinian I pluvial) and /or $\sim 0.2 \mathrm{Ma}$ (Abyssinian I pluvial). These two age assignments closely correspond to age determination of Tufa and cave-filling deposits in western Egypt (Sultan et al., 1997). However, the most distal TBs of the Valley of the Queens may be older, and assignable to an earlier pluvial, i.e., the Armantian (0.8 Ma) or the Idfuan (1.7 Ma) Pluvial (ages from Said, 1990, fig. 25.9, table 15.1). We tentatively attribute the proximal TBs to the younger pluvials ( $<0.2 \mathrm{Myr})$. Mapping of the superficial deposits on the West Bank may help corroborate our non-conventional dating of the formation of the tilted blocks.

$\mathrm{V}-4$. How did slumping occur?

McLane et al. (2003) established a WSW-ENE oriented geological cross-section from Gebel E1 Qurn through the Valley of the Kings and to the New Qurnah Quarry. They showed the presence of tilted blocks at the foot of the Theban Mountain, but did not represent their relationship with the substratum and with one another. This is detailed in a diagrammatic figure from Yehia (1987, in Abdallah and Helal, 1990), that shows correctly the Tarawan Chalk Formation to be the ultimate surface upon which the tilted blocks are anchored (as seen at the toe of the TB of Sheikh Abd el Qurna-El Khokhah). It also shows the tilted blocks in contact along listric faults. This en-echelon configuration implies the initial detachment from the Theban front of a massive tilted block that subsequently broke into several smaller tilted blocks along listric faults, so that the younger distal blocks are also the most distal. The geological evidence discussed above does not support this interpretation. The distal blocks have been structurally deformed as 
$2 / 16 / 11$

they have been pressed against by the more recent proximal blocks, causing reverse faults between consecutive blocks, and warping of the beds at the toe of the more proximal ones.

The formation of the Theban hills may serve as a model for gravitational collapse along the edge of a plateau, where a thick, incompetent, ductile lithology (here the Esna Shale Formation) is overlain by a rigid, porous and fractured rock unit (here the Thebes Limestone Formation). Because they are threats to human settlements, the literature abounds with such cases (see Popescu, 2005 and references therein). The case we discuss here shows that a space must be created between a failing slope and a penultimate collapse structure for an ultimate collapse structure to occur. The space may be produced by erosion causing the slope to recess and the penultimate structure to decrease in size, or by the penultimate structure sliding far enough away from the slope from which it detached, or, most likely, by a combination of the two. Only in this case will the landscape evolve. If insufficient space is created, the penultimate collapse structure buttresses the slope, and no ultimate collapse will occur.

V-5. Consequences of slumping on the landscape.

Our geological mapping of the eastern edge of the Theban Mountain has revealed two prominent geological features. First, the presence of several generations of gravitational collapses along the Theban Front, forming the Theban hills. Second, the slight southwesterly dip of the upper Paleocene strata, causing a subtle but determinant asymmetry in the distribution of lithologies. For instance, topographic level $100 \mathrm{~m}$ the Tarawan Chalk outcrops at the eastern edge of the hills of Sheikh Abd el Qurna and El Khokhah, but the Esna Shale Formation occurs at the bottom of Wadi el-Melikat. This asymmetry is largely responsible for the differential erosion that has affected the lithologies of the Theban hills along a NE-SW transect.

The Theban landscape evolved markedly during the Pleistocene as a result of changes in climatic/hydrogeological regimes (Fig. 22a-d). The (current) Theban hills formed posterior to the filling of the northern Basin in which detrital deposits issued from the erosion of the Theban Plateau collected together with playa deposits. The geographic extent and sedimentary history of the northern basin are not yet unraveled, but heterolithic breccias mold a paleocliff along the northern flank of the Valley of El Deir el Bahari (Fig. 22a). During the filling of the basin, the Theban Plateau formed a promontory that probably protruded markedly to the southwest. Perhaps in connection with a displacement of the (?proto)Nile towards the northwest, the Theban cliff recessed to a position slightly behind the most distal tilted blocks (Fig. 22b). Successive pluvials then caused the emplacement of successive generations of tilted blocks (Fig. 22b, c). The emplacement of the proximal tilted blocks was followed by intensive 
erosion of the Esna Shale Formation, causing notably the formation of the Wadis of Colors and of Deir el Medina, including the intensive erosion of the core of the proximal TB of Deir el Medina (Fig. 22d). As explained above, the relative history of the Theban Hills is generally comprehensively established but its numerical chronology remains to be determined.

The en-echelon agency of the tilted blocks of the Valley of the Queens (Fig. 23a) result in a modern topography in which the landscape is stabilized, with the proximal TB forming a buttress that maintains the Theban front in place. This stabilization should apply, even if deep fractures parallel to the current cliffs should develop along the edge of the Theban plateau. A change to this configuration would first necessitate significant erosion of the proximal TB and clearance of a large area between it and the cliffs and /or a substantial erosional recession of the Theban front.

The situation is the same for the TB of Deir el Medina (Fig. 23b), as far as a gravitational collapse originating from the Theban plateau is concerned. However, this tilted block is highly vulnerable to erosion because the Esna Shale Formation at its core has already been considerably eroded. As we have explained above, the TB of Deir el Medina is now divided in two units. The western unit buttresses the Theban Front, but the eastern unit is part of Qurnet Mura'î. The Valley of Deir el Medina between the two units results from extensive erosion of the Esna shale Formation to a depth of over $30 \mathrm{~m}$. A pluvial episode would doubtlessly lead to the resumption of erosion of the shales, and deepening and widening of the valley. This makes the Village of Deir el Medina and the cemeteries to the east and west of the valley highly vulnerable to the establishment of a pluvial regime. The eastern Hill of Qurnet Mura'î would likely be affected as well, but to a lesser extent.

Even more vulnerable to a pluvial regime are the amphitheater of El Deir el Bahari, the Hills of El Asasif, and the Valley of Colors. The Theban front is unprotected by buttressing hills in the amphitheater of El Deir el Bahari, and gravitational collapse could occur. The TB of Sheikh Abd el Qurna-El Khokhah is evidence of failure of the Theban cliffs and gravitational collapse behind the Valley of Colors (Fig. 23c). The geometry of the amphitheater of El Deir el Bahari itself is characteristic of an area where gravitational collapse has occurred (see Hesthammer and Fossen, 1999). It is likely that gravitational collapse there would produce a TB with a configuration very similar to the western unit of the TB of Deir El Medina (a thick mass of the Esna Shale Formation dipping to the west would form the head of the TB) unless tectonic thinning results in a Sheikh Abd el Qurna-El Khokhah-like TB. Erosion of the Esna Shale Formation $(\sim 80 \mathrm{~m})$ in the Hills of El Asasif would progressively expose the Tarawan Chalk. This, and the erosion of the slope at the base of which lie the temples of Nebhepetre Mentuhotep and Hatshepsut could 
$2 / 16 / 11$

enhance the potential for gravitational collapse. In a model experiment at El Deir el Bahari, Abdallah and Helal (1990) showed that the removal of screes and an increase of the slope to $51^{\circ}$ would markedly increase the risk of sliding. On another hand a tilted block would probably not progress far to the east, its sole resting on the outcropping competent Tarawan Chalk. Erosion would also be significant in the Valley of Colors, and the Hills of Sheikh Abd el Qurna and El Khokhah would probably become more prominent in the landscape.

\section{Conclusions}

We have described the Theban Hills in terms of groups of imbricate distal and proximal tilted blocks of lower Eocene rocks that have become detached en masse from the Libyan plateau. The NW oriented concave listric faults were easily followed in outcrop beneath the proximal tilted blocks. However, only the nearly horizontal portion of the listric faults, along the decollement, is now preserved in the distal tilted blocks. Up to the present, we have failed to locate them. In the mass transport complexes of the Valley of the Queens and Deir el Medina, the proximal blocks abut the adjacent distal blocks along a reverse fault, the strata at the head of the proximal blocks exhibiting a marked warping, firm evidence that the latter result from more recent gravitational collapse. This required clarification because of earlier graphic interpretation of the relationship between tilted blocks within a mass transport complex.

We have attempted to relate the sequence of gravitational collapses to the climatic history of Upper Egypt, and more generally the Sahara Desert, by inferring that gravitational collapse was induced by intense rainfalls during Pleistocene pluvials, the timing of which was deduced from the history of fluvial sedimentation in the Nile Valley (Said, 1981, 1990, 1993). We very tentatively propose that the oldest, more distal tilted blocks of the Valley of the Queens were emplaced during the early Pleistocene Idfuan pluvial ( $\sim 1.7 \mathrm{Ma}$ ) or more likely during the middle Pleistocene Armantian pluvial ( $\sim 0.7 \mathrm{Ma})$. The youngest distal tilted blocks may result from slope failure during the Abyssinian I ( 0.4 Ma) and Abyssinian II ( $\sim 0.2 \mathrm{Ma})$ pluvials. If so the proximal tilted blocks would have been associated with more recent pluvials (e.g., Saharan Pluvial). Intensive erosion during the most recent pluvials (e.g., Nabatian) would have fashioned the modern landscape, causing a valley to open at the core of the proximal tilted block of Deir el Medina, and clearing the amphitheater of El Deir el Bahari from any traces of earlier slope failures.

The Theban landscape will probably remain stable under the current hyper arid conditions that characterize Upper Egypt. However, the Theban hills will likely undergo significant morphological 
evolution during the next pluvial episode. The degree of change would decrease from northeast to southwest, as a result of both the distribution of the Esna Shale Formation in outcrop and the position of the proximal tilted blocks with respect to the Theban front. The most vulnerable part of the Theban area is the amphitheater of El Deir el Bahari, carved in the ductile Esna Shale Formation, dominated by the highly fractured Thebes Limestone Formation, and unprotected from erosion. The less vulnerable part is the complex of the Valley of the Queens because of the role of buttress played by the proximal tilted block (in which the tombs of the Queens are cut).

The Theban Mountain is a remarkable example of the effect that climate coupled with geology have on shaping the evolution of a landscape. Geology has been given little consideration, and climatic change has been ignored, in the long-term planning for the preservation and management of the Theban Mountain. This study shows that ultimately efforts for the conservation of the Antiquities on the West Bank will be successful only if long-term planning takes into consideration the intricate interplay between geology and climate.

Acknowledgements. We are grateful to the National Geographic Society for its continued support of our geological research on the Theban Mountain; to Dr. H. Ghaly for initiating this work, to him and Prof. R. Said for their continued and enthusiastic encouragement; to the Supreme Council of the Antiquities, in particular Dr. M. I. Khaled, for authorizing us to conduct geological research on the West Bank and for promoting the TIGA project; and to the University of Assiut for invaluable technical assistance in the course of this research. Robert Knox publishes with the approval of the Executive Director of BGS (Natural Environment Research Council). We are indebted to our colleagues from Assiut University, in particular Profs. Kh. Ouda and M. Youssef, for their collaboration, and to our archeologist colleagues, in particular K. Weeks and M. Leblanc for discussion and guidance with regard to geoarcheological problems in Thebes. We thank Dennis Kent and Martha Withjack (Rutgers University) for discussion, Emily Poorvin for field assistance, and XXX and XXX for their thoughtful reviews of the manuscript.

\section{References}

Abdallah, T., and Helal, H., 1990. Risk evaluation of rock mass sliding in El-Deir El-Bahari Valley, Luxor, Egypt. Bulletin of the International Association of Engineering Geology de l'Association internationale de Géologie de l'Ingenieur, $n^{\circ}$ 42, p. 3-9.

Aubry, M.-P. 1996, Towards an upper Paleocene-lower Eocene high resolution stratigraphy, in: Aubry, M.-P. and Benjamini, C., Paleocene/Eocene Boundary Events, Israel Bulletin of Earth Sciences 44, 239-253. 
$2 / 16 / 11$

Aubry, M.-P., Ouda K., Dupuis C., Berggren W. A., Van Couvering J. A. and the members of the Working Group on the Paleocene/Eocene Boundary, 2007, The Global Standard Stratotype-section and Point (GSSP) for the Eocene Series in the Dababiya section (Egypt). Episodes 30, 271-286.

Aubry, M.-P., Berggren, W. A., Dupuis, C., Ghaly, H., Ward, D., King, C., Knox, R. O’B., Ouda, K., Youssef, M., and Hassan, W. F., 2009a. Pharaonic Necrostratigraphy: A review of geological and archeological studies in the Theban Necropolis, Luxor, West Bank, Egypt. Terra Nova 21, 237-256.

Aubry, M.-P., Berggren, W. A., Hilgen, F., McGowran, B., Steininger' F., Lourens,L., 2009b. The Neogene and Quaternary: chronostratigraphic compromise or Non-overlapping Magisteria? Stratigraphy 6, 1-16.

Aubry, M.-P., Van Couvering, J.A., Christie-lick, N., Landing, E., Pratt, B.R., Owen, D.E., Ferrusquía, I.-V., 2009c. Terminology of geological time: Establishment of a community standard. Stratigraphy 6, 100-105.

Aubry, M.-P., Dupuis, C., Ghaly, H., King, C., Knox, R. O’B., Berggren, W. A., Karlhausen, C., and Members of the TIGA Project, 2011. Geological setting of the Theban Necropolis: Implications for the preservation of the West Bank monument. Leuven, Belgium: PEETERS Publishers.

Aubry, M.-P., Berggren, W. A., Dupuis, C., Poorvin, E., Ghaly, H., Ward, D., King, C., Knox, R. O’B., Ouda, K., Youssef, M., and Galal, W. F., in press. TIGA: A geoarcheological Project in the Theban Necropolis, West Bank, Luxor, Egypt. Proceedings of the X International Congress of Egyptologists, Rhodes, May 2008.

Baraize, E., 1904-1913. Plan des Nécropolis Thébaines. Service des Antiquités de l'Egypte, Cairo: General Survey Printing Office. 1:1000 maps C3-C7, D3-D7, E1-E5, F1-F4, G3.

Berggren, W.A., 1998. The Cenozoic Era: Lyellian (chrono)stratigraphy and nomenclatorial reform at the millennium, in: Blundell, D. J. and Scott, A. C., (eds.), Lyell: The Past is the Key to the Present, Geological Society Special Publication no. 143, 111-132.

Bridgland, D.R., Keen, D., and Westaway, R., 2007. Global correlation of Late Cenozoic fluvial deposits" A synthesis of data from IGCP 449. Quaternary Science Reviews 26, 2694-2700.

Bridgland and Westaway, 2008a. Preservation patterns of Late Cenozoic fluvial deposits and their implications: Results from IGCP 449. Quaternary International 189, 5-38.

Bridgland and Westaway, 2008b. Climatically controlled river terrace staircases: A worldwide Quaternary phenomenon. Geomorphology 98, 285-315.

Brookes, I. A., 1993. Geomorphology and Quaternary geology of the Dakhla Oasis region, Egypt. Quaternary Sciences Reviews 12, 529-552. 
$2 / 16 / 11$

Capuani, M., Meinardus, O. F. A., Rutschowscaya, M.-H., 2002. Christian Egypt: Coptic Art and Monuments Through Two Millenia. Cairo: The American University in Cairo Press, 272 pp.

Churcher, C. S., Kleindiest, M. R., Schwarz, H. P., 1999. Faunal remains from the middle Pleistocene lacustrine marls in Dakhleh Oasis, Egypt: Paleoenvironmental reconstructions. Palaeogeography, Palaeaoclimatology, Palaeoecology 154, 301-312.

Cobbold, P., Watkinson, J., and Cosgrove, J., 2008. Did the pharaohs of Egypt make their tombs in solid rock on the Theban Plateau? Geoscientist 18, 19-22.

Crombie, M.K., Arvidson, R.E., Sturchio, N.C., Alfy, Z.E., and Zeid, K.A., 1997. Age and isotopic constraints on Pleistocene pluvial episodes in the Western Desert, Egypt: Palaeogeography, Palaeoclimatology, Palaeoecology 130, 337-355, doi: 10.1016/S0031-0182(96)00134-4.

Curtis, G. H., 1979. The geology of the Valley of the Kings, Thebes, Egypt. Theban Royal Tomb Project, The Brooklyn Museum Theban Expedition. Unpublished. Brooklyn Museum.

Dupuis, C., Aubry, M.-P., Steurbaut, E., Berggren, W.A., Ouda, Kh., Magioncalda, R., Cramer, B.S., Kent, D.V., Speijer, R.P., and Heilmann-Clausen, C., 2003. The Dababiya Quarry Section: Lithostratigraphy, clay mineralogy, geochemistry and Paleontology. Micropaleontology 49, Supplement, 41-59.

Finney, S. C., 2010. Formal definition of the Quaternary System/Period and redefinition of the Pleistocene Series/Epoch. Episodes 33, 159-163.

Fronaberger A. K., 2002, Preliminary report on the geology and structural stability of three Theban tombs, TT72, TT121, and MMA850. Serapis Research Institute (2002), 1-16.

Hamdan, M. A., 2000. Quaternary travertines of Wadis Abu Had-dib area Eastern Desert, Egypt: paleoenvironment through field, sedimentology, age, and isotopic study. Sedimentology of Egypt, 8, $49-62$.

Hesthammer, J. and Fossen, H., 1999. Evolution and geometries of gravitational collapse structures with examples from the Statfjord Field, northern North Sea. Marine and Petroleum Geology 16, 259-281.

Hoelzmann, P., Kruse, H.-J., and Rottinger, F., 2000. Precipitation estimates for the eastern Saharan palaeomonsoon based on a water balance model of the West Nubian palaeolake basin. Global and Planetary Change 26, p. 105-120, doi: 10.1016/S0921-8181(00)00038-2.

Kieniewicz, J.M., and Smith, J.R., 2007. Hydrologic and climatic implications of stable isotope and minor element analyses of authigenic calcite silts and gastropod shells from a midPleistocene pluvial lake, Western Desert, Egypt: Quaternary Research 68, 431-444.

Kieniewicz, J.M., and Smith, J.R., 2007. Hydrologic and climatic implications of stable isotope and minor element analyses of authigenic calcite silts and gastropod shells from a midPleistocene pluvial lake, Western Desert, Egypt: Quaternary Research 68, 431-444. 
$2 / 16 / 11$

Kliendienst, M. R., Schwarcz, H. P., Nicoll, K., Churcher, C. S., Frizano, J., Giegengack, R., Wiseman, M. F., 2006. Water in the desert: First report on Uranium-series dating of Caton-Thompson's and Gardner's "Classic" leistocene sequence of Refuf Pas, Kharga Oasis, in: Wiserman, M. F., (Ed.), Oasis Papers II: Proceedings of the Second Dakhleh Oasis Project Research Seminar. Oxford: Oxbow Books.

Lourens, L.J., Hilgen, F.J., Laskar, J., Shackleton, N.J., and Wilson, D., 2004. The Neogene Period, in: Gradstein, F.M., Ogg, J.G., and Smith, A.G. (Eds.), A Geologic Time Scale 2004, 409-440. Cambridge: Cambridge University Press.

Lyell, C., 1833. Principles of Geology. London: John Murray. Vol. 3, 1833, 398 pp. +160 p. appendices [1990 reprint by the University of Chicago Press, with a new introduction by M. J. S. Rudwick].

Lyell, C., 1839. Nouveaux éléments de Géologie. Pitois-Levranet, Paris.

Martini, E., 1971. Standard Tertiary and Quaternary calcareous nannoplankton zonation, in: Farinacci, A. (Ed.), Proceedings of the II Planktonic Conference, Roma, 1970, 2, Rome, Ediz. Tecnoscienza, p. 739-785.

McLane, J., Wust, R. A. J., Porter, B., and Rutherford, J., 2003. Flash flood impacts and protection measures in the Valley of the Kings, Luxor, Egypt. APT Bulletin 34, 37-45.

Nicoll, K., 2001. Radiocarbon chronologies for prehistoric occupation and hydroclimatic change in Egypt and northern Sudan. Geoarcheology 16, 47-64.

Nicholson, S. E., and Flohn, H., 1980. African environment and climatic change and the general atmospheric circulation in late Pleistocene and Holocene. Climate change 2, 313-348.

Poorvin, E., 2010. Scaled experimental models of gravitational collapse: analysis of structures formed during creation and retreat of erosional scarps. Unpublished Master of Science, Rutgers University.

Popsecu, M. E., 2005. Landslides causal factors and landslides remediatial options. Illions Institute of Technology, Chicago, USA, 21 pp.

Said, R., 1975. The Geological Evolution of the River Nile, in: Problems in Prehistory Northern Africa and the Levant, Wendorf, F., and Marks, A. E. (eds.), Southern Methodist University Press, Dallas, TX, 1-44.

Said, R., 1981. The Geological Evolution of the River Nile. New York: Springer-Verlag, 151 pp.

Said, R., 1983. Proposed classification of the Quaternary of Egypt. Journal of African Earth Sciences 1, 41-45.

Said, R., 1990. Quaternary. In Said, R., The Geology of Egypt, Rotterdam: Balkema, 487-507. 
$2 / 16 / 11$

Said, R. 1993. The River Nile, Geology, hydrogeology and utilization. Oxford: Pergamon Press, 320 pp.

Sandford, K.S., and Arkell, W.J., 1939. Paleolithic man and the Nile Valley in Nubia and Upper Egypt. Chicago University Oriental Institute Publication 36, 1-105.

Smith, J.R., Giegengack, R., and Schwarcz, H.P., 2004. Constraints on Pleistocene pluvial climates through stable-isotope analysis of fossil-spring tufas and associated gastropods, Kharga Oasis, Egypt. Palaeogeography, Palaeoclimatology, Palaeoecology 206, 157-175, doi:

10.1016/j.palaeo.2004.01.021.

Sultan, M., Sturchio, N., Hassan, F.A., Hamdan, M. A. R., Mahmood, A. M., Alfy, Z. E., and T. Stein, 1997. Precipitation Source Inferred from Stable Isotopic Composition of Pleistocene Groundwater and Carbonate Deposits in the Western Desert of Egypt. Quaternary Research 48, 29-37.

Szabo, B.J., Haynes, C.V., and Maxwell, T.A., 1995. Ages of Quaternary pluvial episodes determined by uraniumseries and radiocarbon dating of lacustrine deposits of Eastern Sahara. Palaeogeography, Palaeoclimatology, Palaeoecology 113, 227-242, doi: 10.1016/0031-0182(95)00052-N.

Van Couvering, J.A., 2010. The Gelasian question: options in the definition of Pleistocene for manuscripts submitted to our journals. Stratigraphy 7, 228.

Van Couvering, J.A., Aubry, M.-P., Berggren, W.A., Gradstein, F.M., Hilgen, F.J., Kent, D.V., Lourens, L.J., McGowran, B., 2009. What, if anything, is Quaternary? Episodes, 32 (2), 1-2.

Weeks, K., 2001. The treasures of the Valley of the Kings. Cairo: The American University in Cairo Press, 434 pp.

Wendorf, F., Schild, R., and A. E. Close (eds.), 1993. Egypt During the Last Interglacial: The Middle Paleolithic of Bir Tarfawi and Bir Sahara East. New York

Yehia, M. A., 1987. Contribution to the geology of Gebel Gurnah, Luxor, Nile Valley. Bulletin of the Geological Survey, Egypt.

Yehia, M. A., Abdallah, A. M., and Hamroush, H., 1982. Geomorphology of the Nagada region, Upper Egypt. Qatar University, Scientific Bulletin 2, 251-262.

Zaki, R., 2007. Pleistocene evolution of the Nile Valley in northern Upper Egypt. Quaternary Science Reviews 26, 2883-2896. 


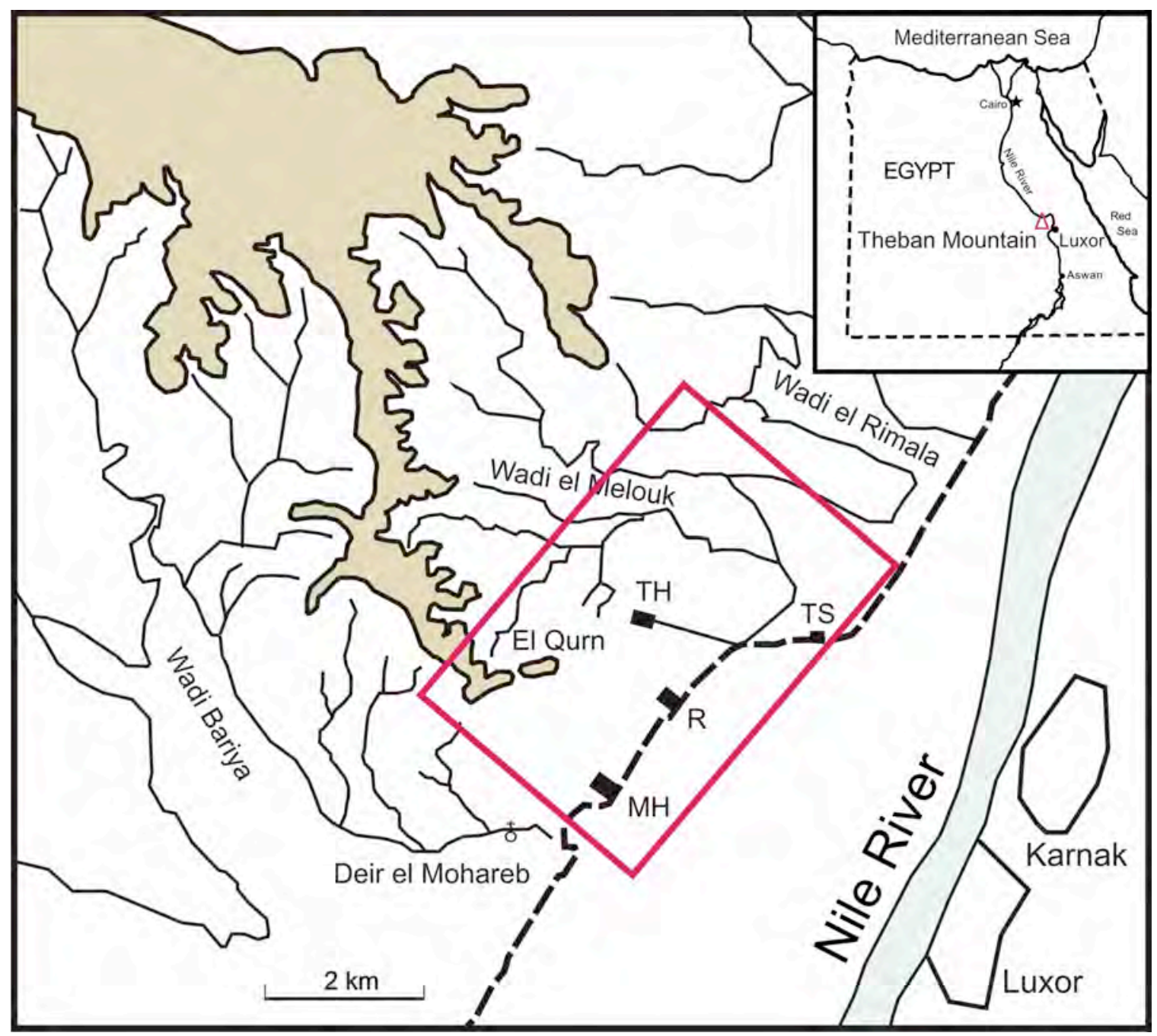

Figure 1. Location map, showing the extent of the cliffs at Thebes (shaded area), and the western limit of the flood plain of the Nile River (dashed line) (after Said, 1981). Rectangle delineates study area.TS:

Temple of Seti I; R: Ramesseum, MH: Medinet Habou; TH: Temple of Hatshepsut in the amphitheatre of El Deir el Bahari. Inset: Map of Egypt. 


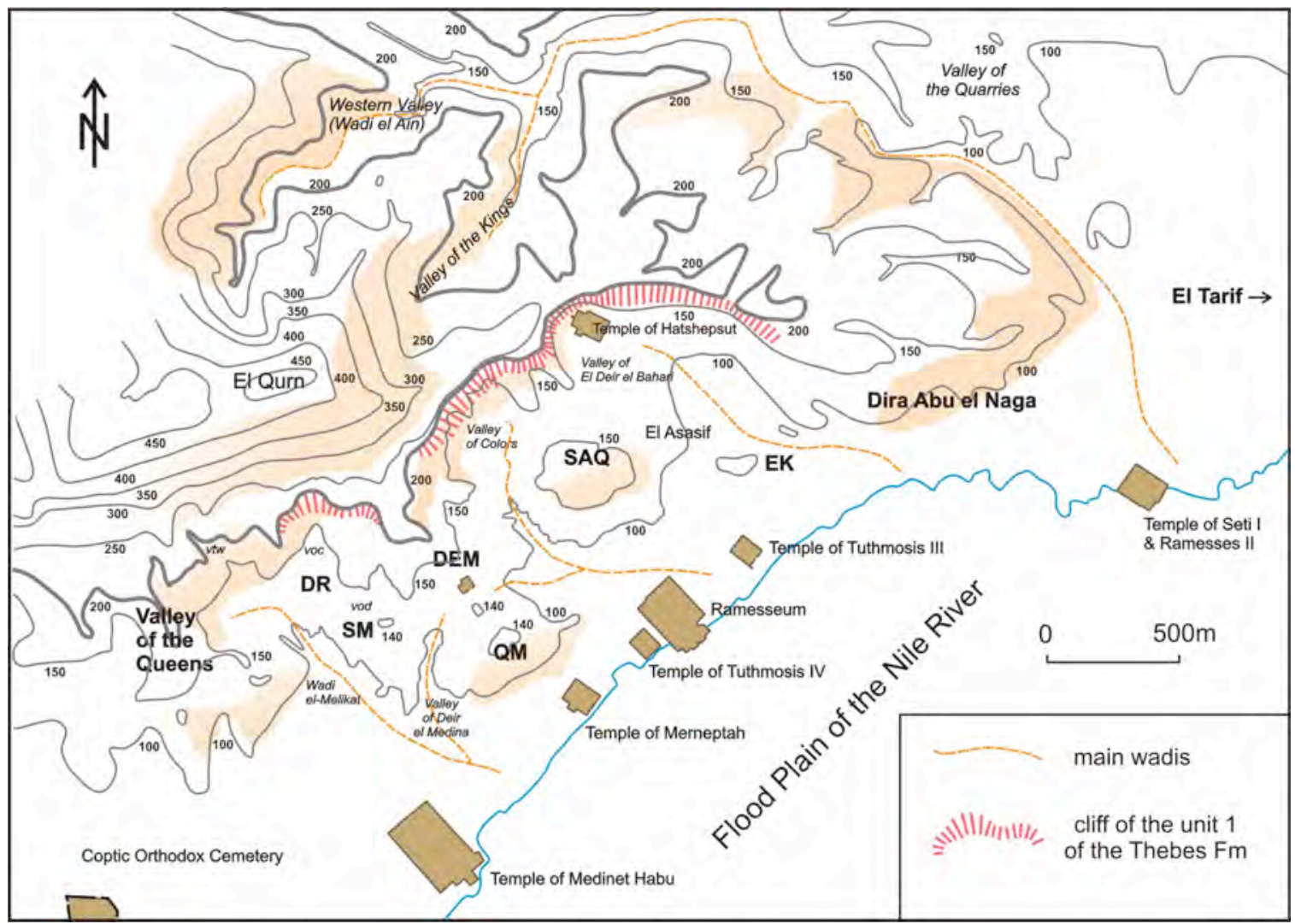

Figure 2. Topographic map of the study area. The three main valleys oriented perpendicular to the cliffs, the narrow Valley of Deir el Medina perpendicular to the Valley of the Queens, and the three shallow depressions delineate a system of hills arranged in quincunx and radiating from the cliff front. In this study "cliff front" refers solely to the eastern edge of the Theban Plateau where the horizontal stratification (tabular structure) characteristic of this unit was exploited for a magnificent architectural effect in the Deir El Bahari temple. The Theban Plateau is the eastern part of the Libyan Plateau. We use the term Valley of the Queens in a geographic, not archeological sense. In the apparent absence of a better name, we extend the definition of Valley of Colors to include the passage between the Hills of Sheikh Abd el Qurna and Qurnet Mura'î. DEM: Deir El Medina; DR: Deir el Rami; EK: El Khokhah; SAQ: Sheikh Abd el Qurna; QM: Qurnet Mura'î; SPM: Sanctuary of Ptah and Meretseger; voc: Valley of the Cord; vod: Valley of the Dolmen; vtw: Valley of the Three Wells. 


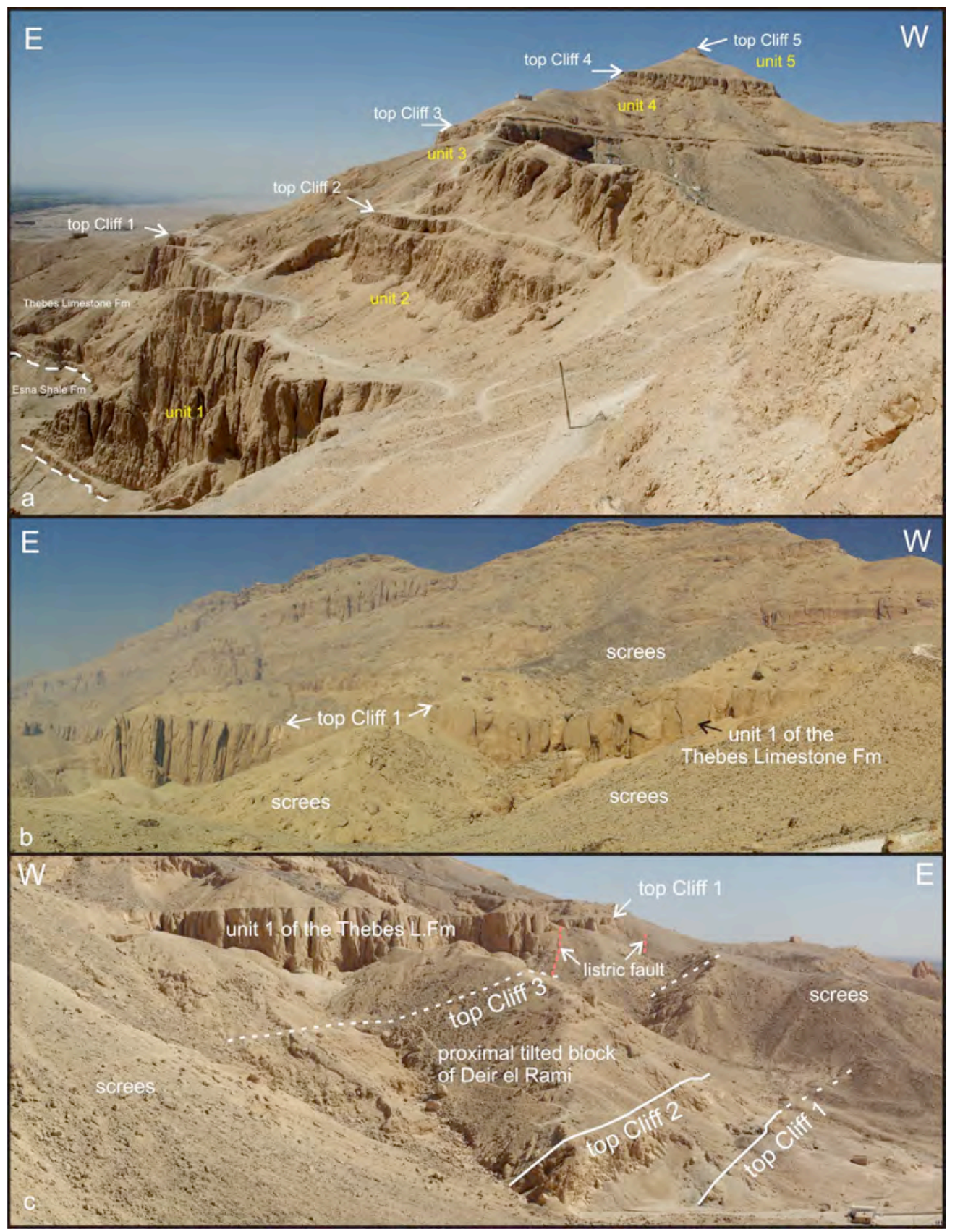

Figure 3. The Theban cliffs at the eastern edge of the Theban Plateau (a). The Theban Front (Cliff 1) is locally interrupted by screes (b) and tilted blocks (c; here the TB of Deir el Rami). 


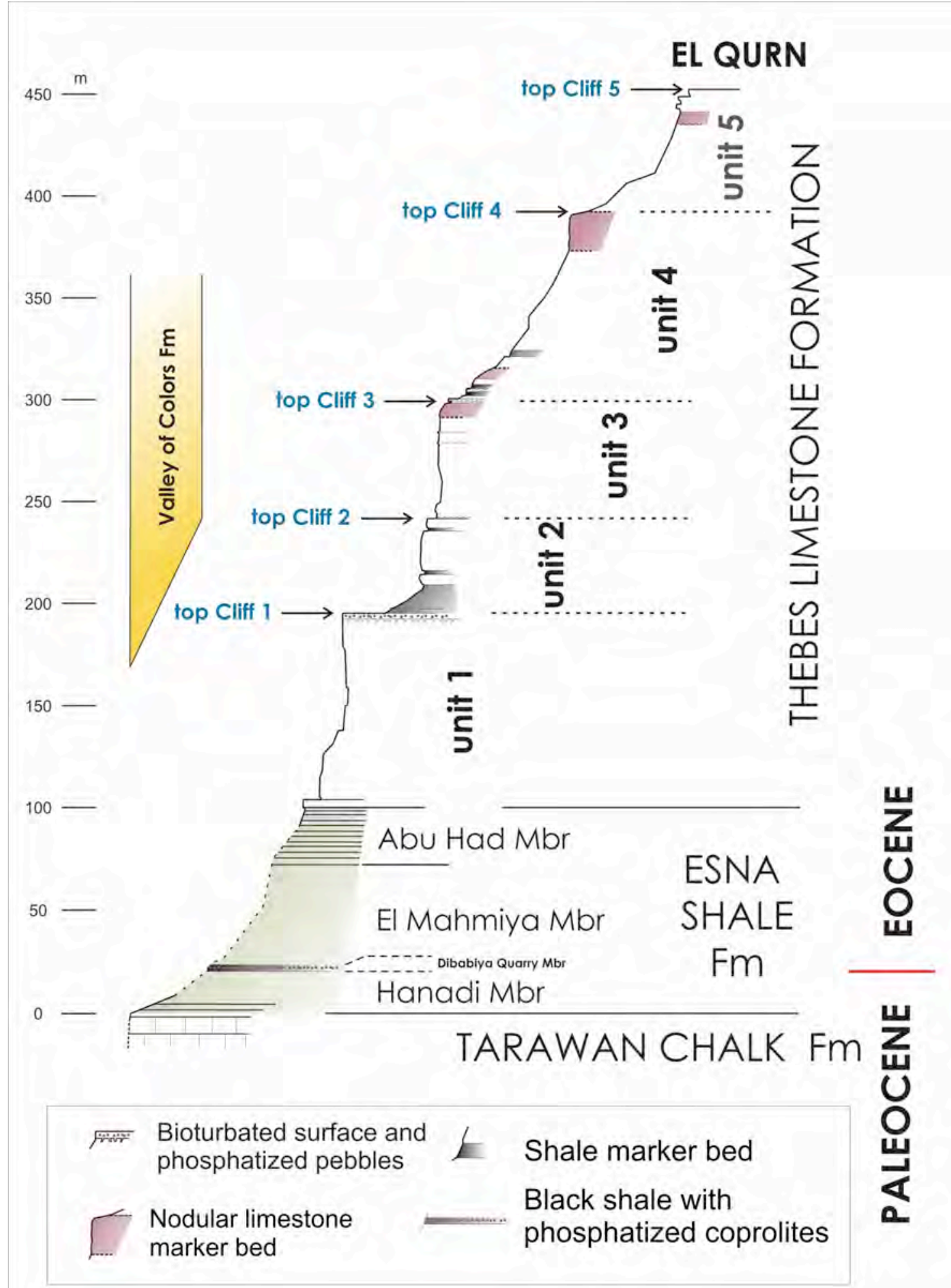


$2 / 16 / 11$

Figure 4. Elements for lithostratigraphic correlations in the Theban Mountain. The section through the Thebes Limestone Formation has been precisely measured (King et al., unpublished). Measurement and description of the Esna Shale Formation are in progress and estimated here. 


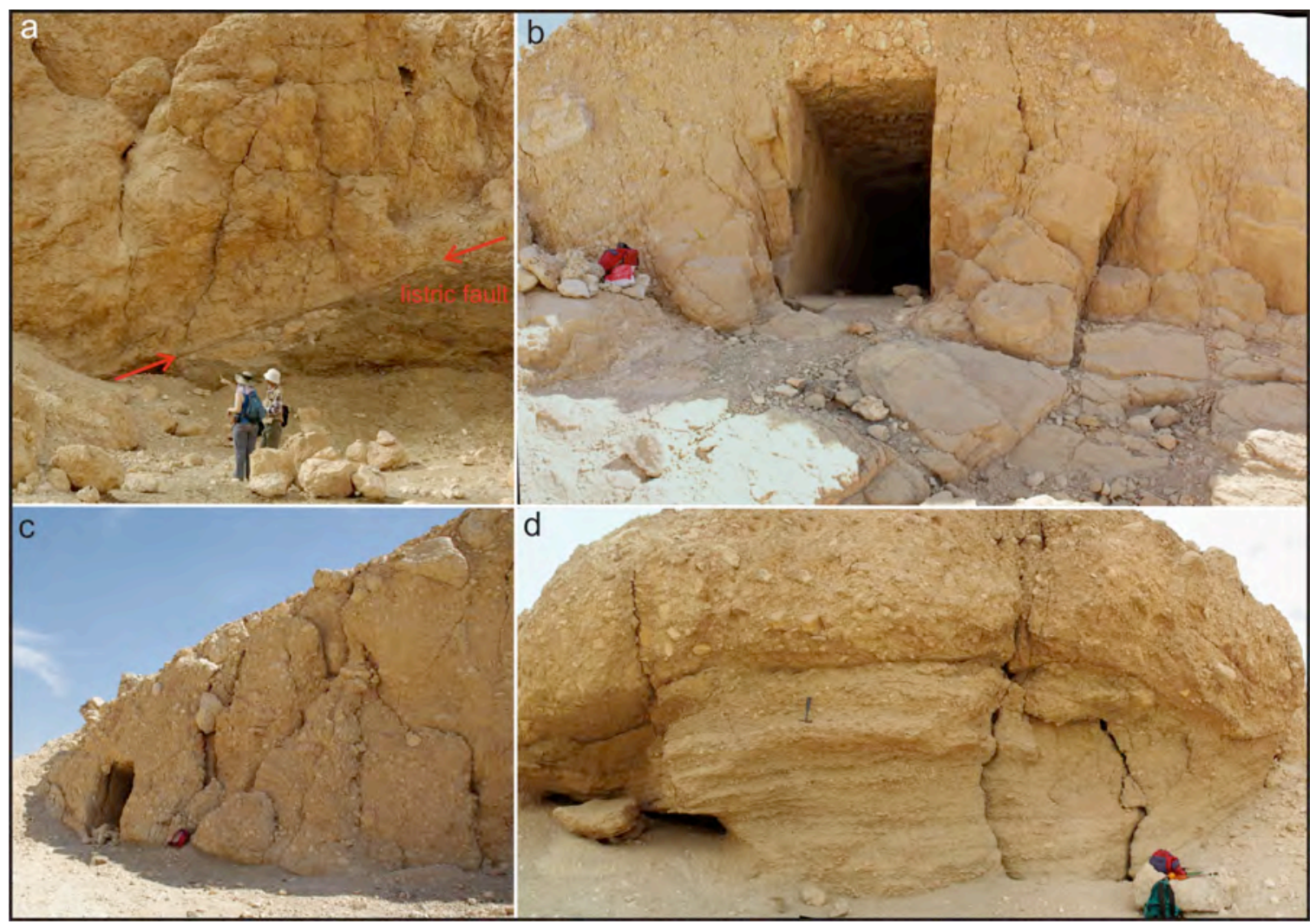

Figure 5. The Valley of Colors Formation

(a): southern face of the Valley of Colors. Note the heterogenous size of the components of the breccia and its listric contact with the Esna Shale (see also Figure 14b)

(b): western face of the Valley of Colors. Note the change in lithology from fine-grained to coarse breccia; note that the ceiling of the tomb is at the contact between the fine and coarse lithologies

(c): western face of the Valley of Colors. heterogeneous breccia

(d): northwest face of the Valley of Color.: Stratified breccia overlain by heterolithic breccia 


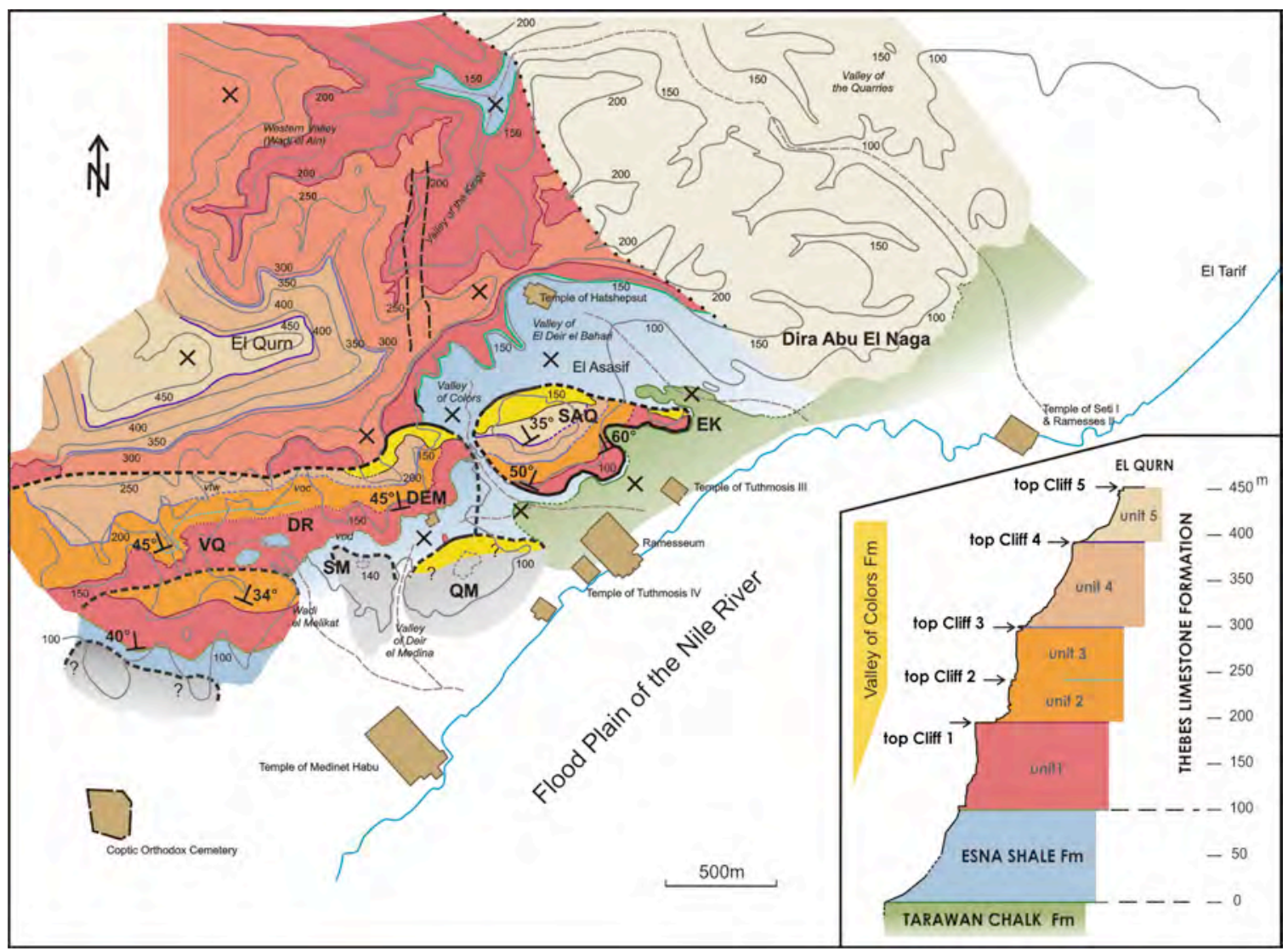

Figure 6. Geological map. Note that the boundaries between lithologic units of Cliffs 2 to 5 follow the topography whereas Cliff 1 (unit 1) is discontinuously exposed. Abbreviations as in Fig. 2.

Grey: distal tilted block with currently undeciphered geology. Tan: the Northern Basin; ltihostratigraphic description in progress. 


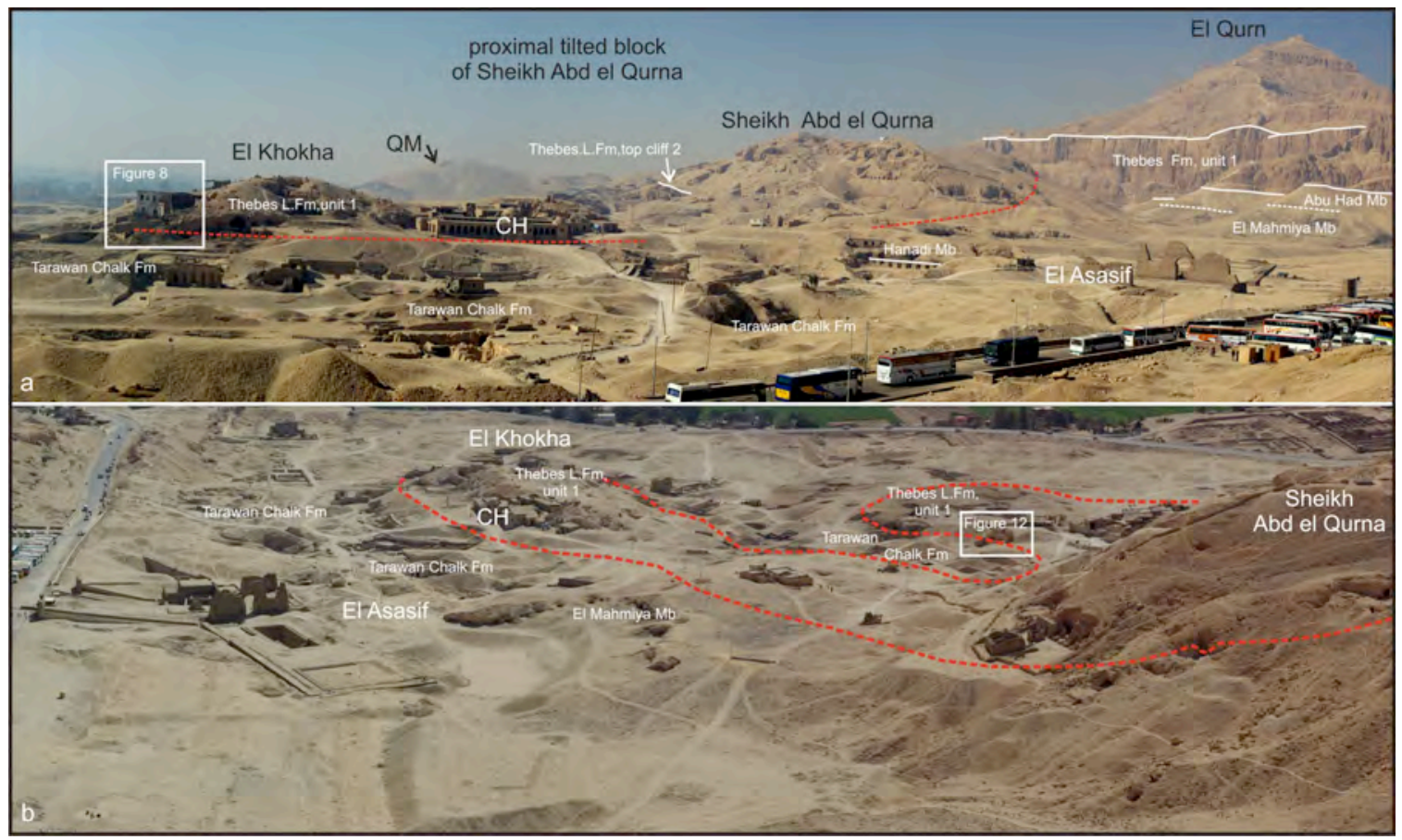

Figure 7. The Hills of Sheikh Abd el Qurna and El Khokhah.

a: Northeast flank of the hills as seen from the Valley of El Deir el Bahari. The Hills of El Asasif are formed by the substratum (Tarawan Chalk Formation to El Mahmiya Member of the Esna Shale Formation). Stratigraphic continuity with the Abu Had Member of the Esna Shale Formation is seen in the steep slopes below the vertical cliffs in unit 1 of the Thebes Limestone Formation. Note the Hills of Qurnet Mura'î (QM) in the background. CH: (ex) Chicago House. Dashed red line: listric fault at the contact between the substratum (Hill of El Asasif) and the Sheikh Abd el Qurna-El Khokhah TB.

b. The low Hill of El Khokhah in the prolongation of the Hills of Sheikh Abd el Qurna. Differential erosion has divided a single tilted block (Sheikh Abd el Qurna-El Khokhah TB) into two geomorphologic groups. The listric contact between substratum and tilted block is delineated by dashed red line. 


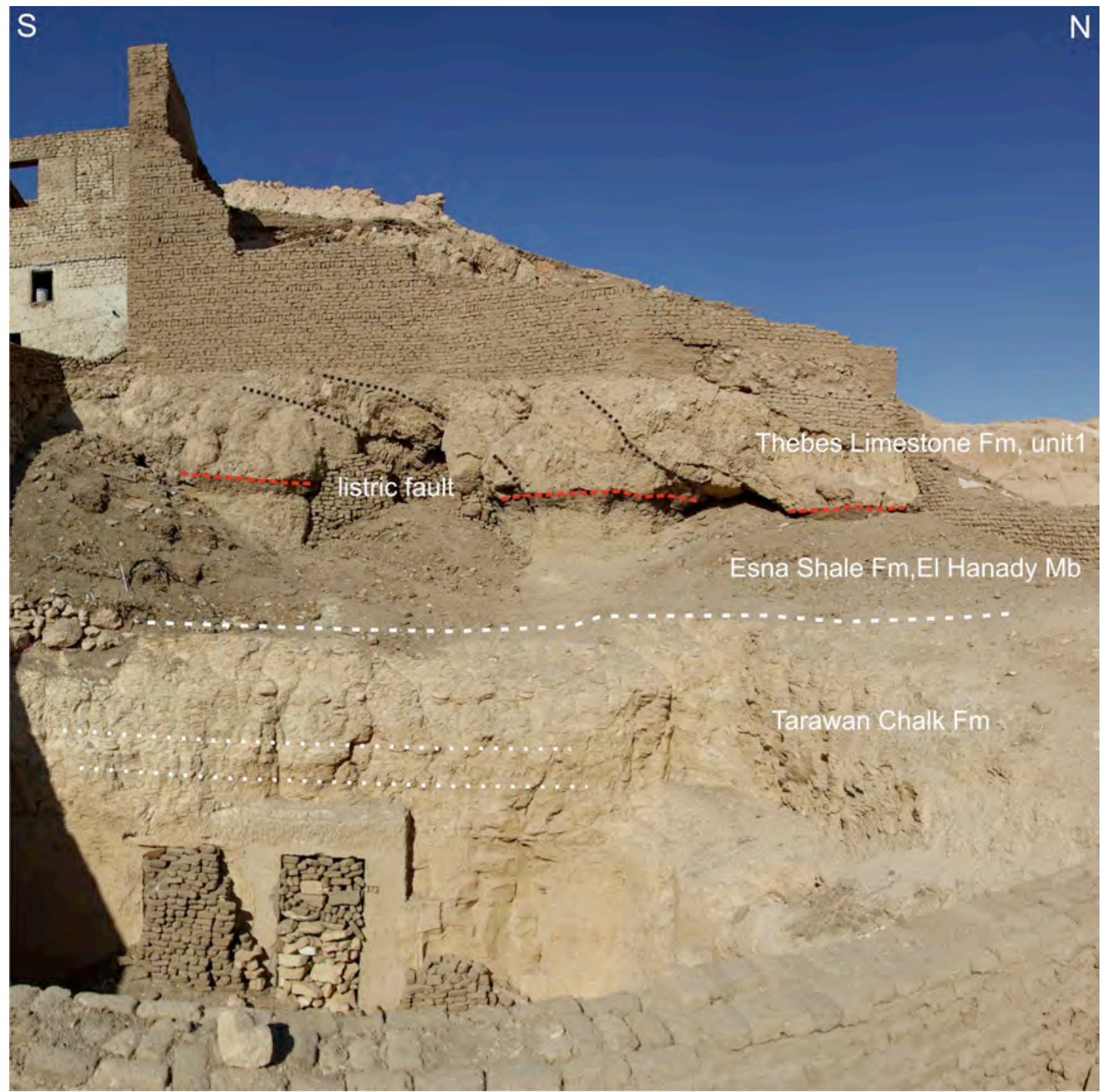

Figure 8. Head of the Sheikh Abd el Qurna-El Khokhah TB, as seen in the east facing flank of the Hill of El Khokhah: Listric contact between the horizontally stratified Tarawan Chalk Formation (= tabular substratum, Hills of El Asasif) and the fractured, $40^{\circ} \mathrm{NW}$ dipping beds of the basal limestone of unit 1 of the Thebes Limestone Formation (TB). A thin package of Esna Shale Formation separates the two calcareous units. See location in Figure 7a. 


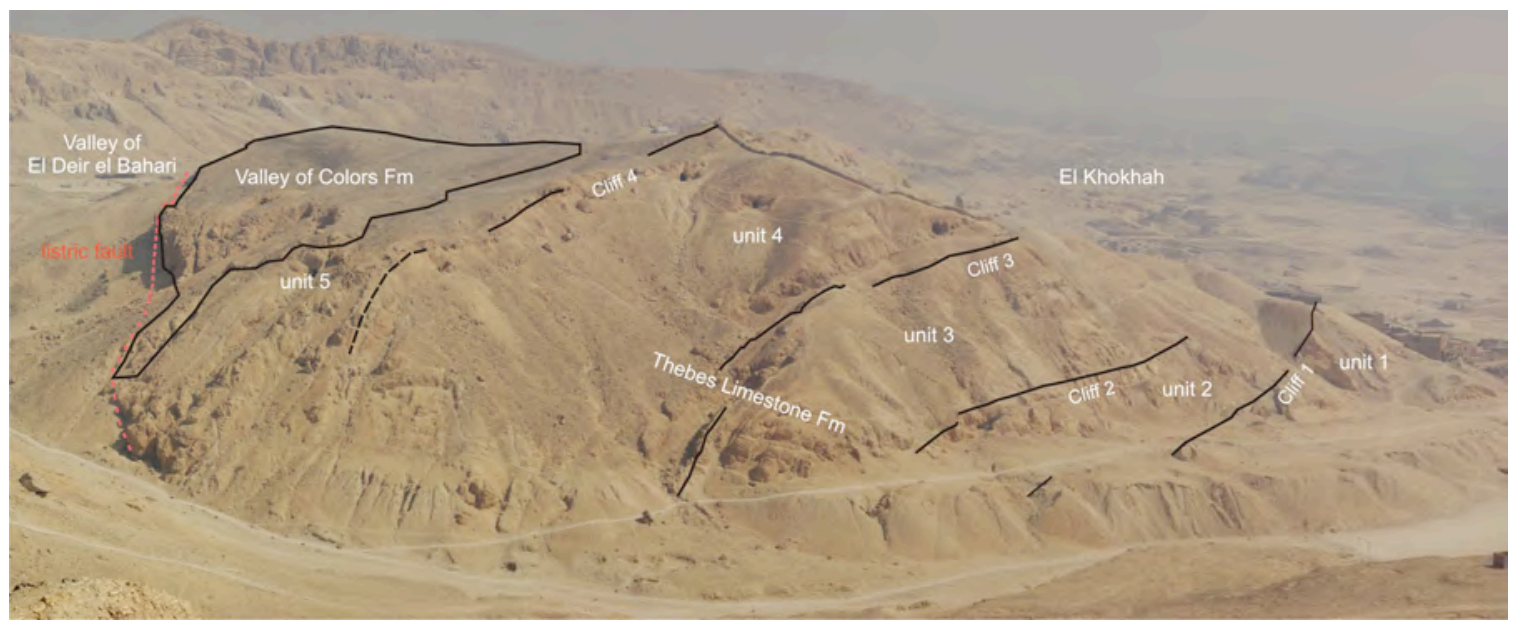

Figure 9. Southwestern flank of the Hills of Sheikh Abd el Qurna as seen from the Theban Cliffs above the Valley of Colors. Note the Valley of El Deir el Bahari (left) and the Hill of El Khokhah (right) in the background. 


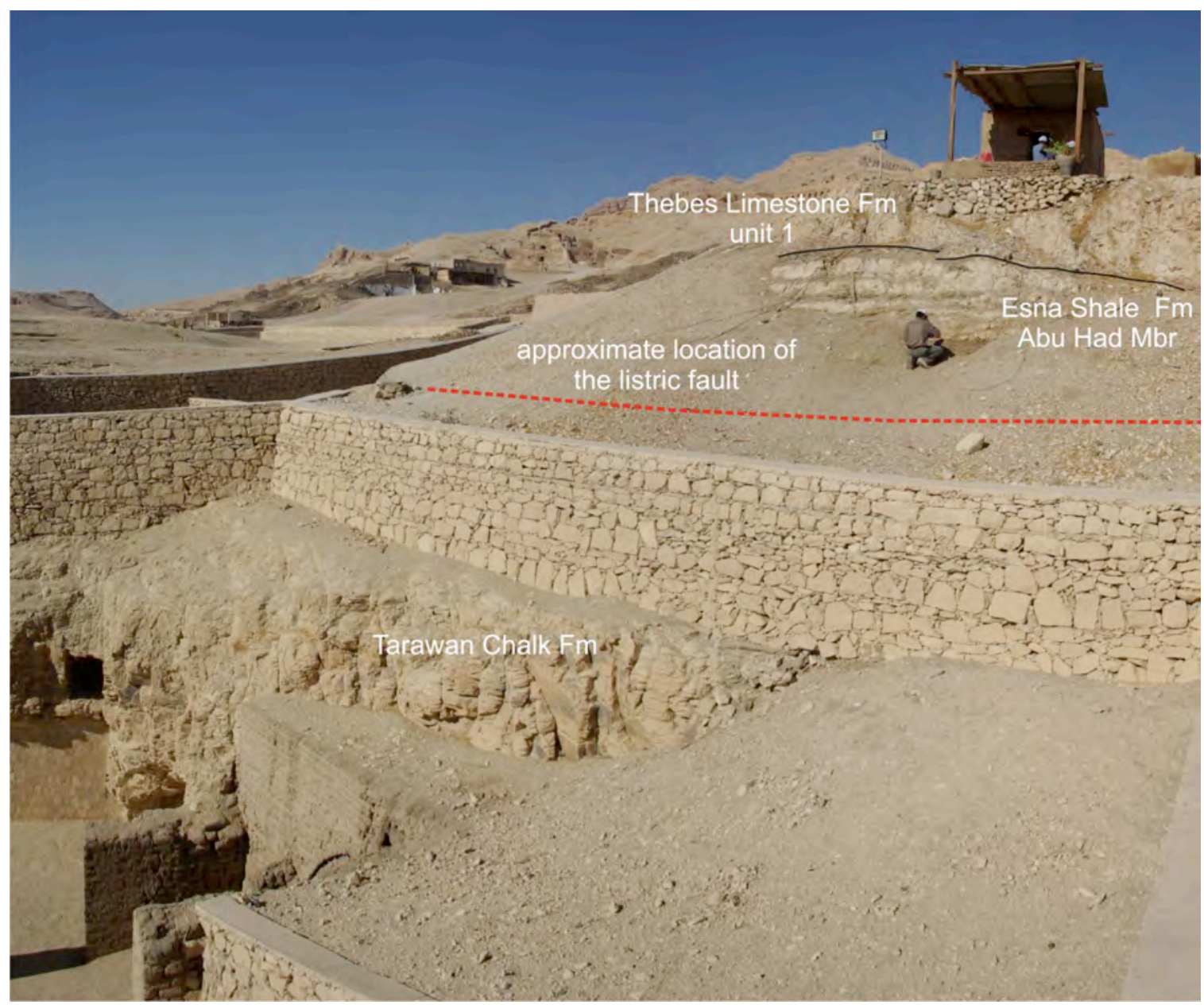

Figure 10. Southeastern flank of the Hills of Sheikh Abd el Qurna exhibiting the anomalous superposition caused by a listric fault at the contact between the substratum (Tarawan Chalk) and the tilted block (Abu Had Member and Thebes Limestone Formation). 


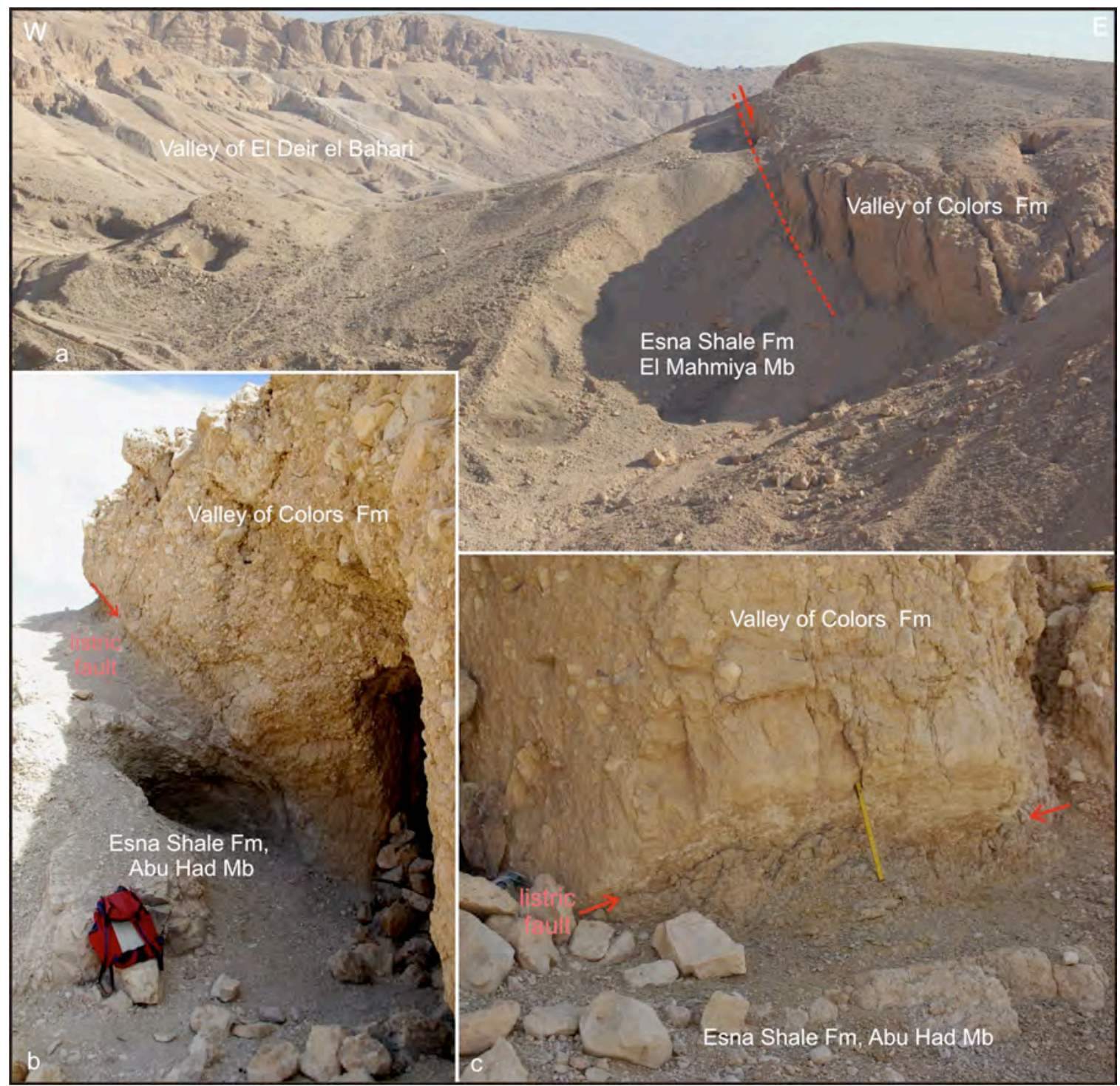

Figure 11. Southwestern flank of the Hills of Sheikh Abd el Qurna exhibiting the listric contact between the substratum (Esna Shale Formation) and the Valley of Colors Formation. a. General view. b, c. Details of the listric fault. Note the ruler $(20 \mathrm{~cm})$ for scale in $\mathrm{c}$. 


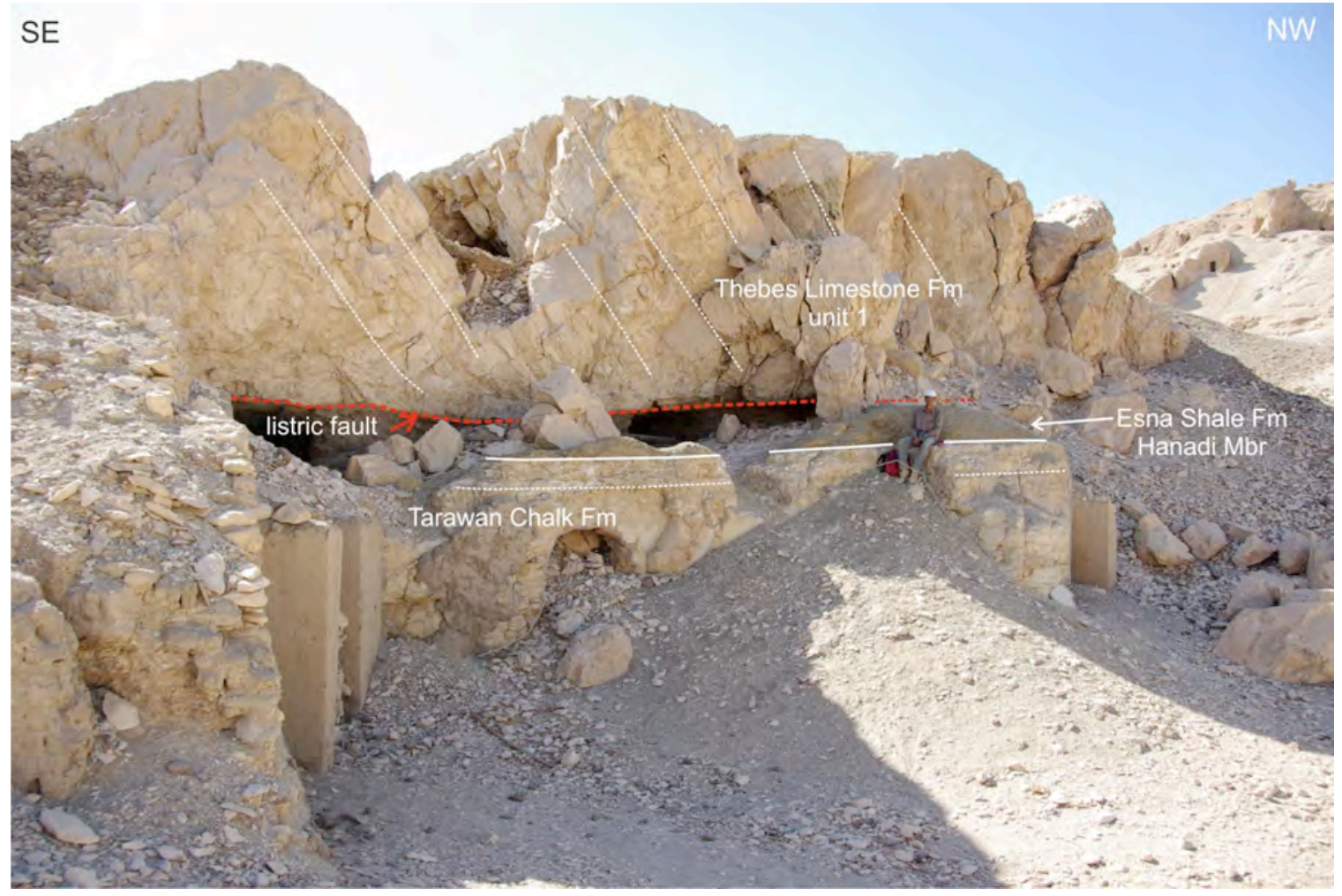

Figure 12. Listric contact between unit 1 of the Thebes Limestone Formation and the Tarawan Chalk Formation as seen at the toe of the TB of Sheikh Abd el Qurna-El Khokhah in the shallow depression between the Hills of Sheikh Abd el Qurna and the Hill of El Khokhah. Note the horizontal stratification of the Chalk, and the $60^{\circ} \mathrm{NW}$-dipping strata of unit 1. See location in Fig. $7 \mathrm{~b}$. 


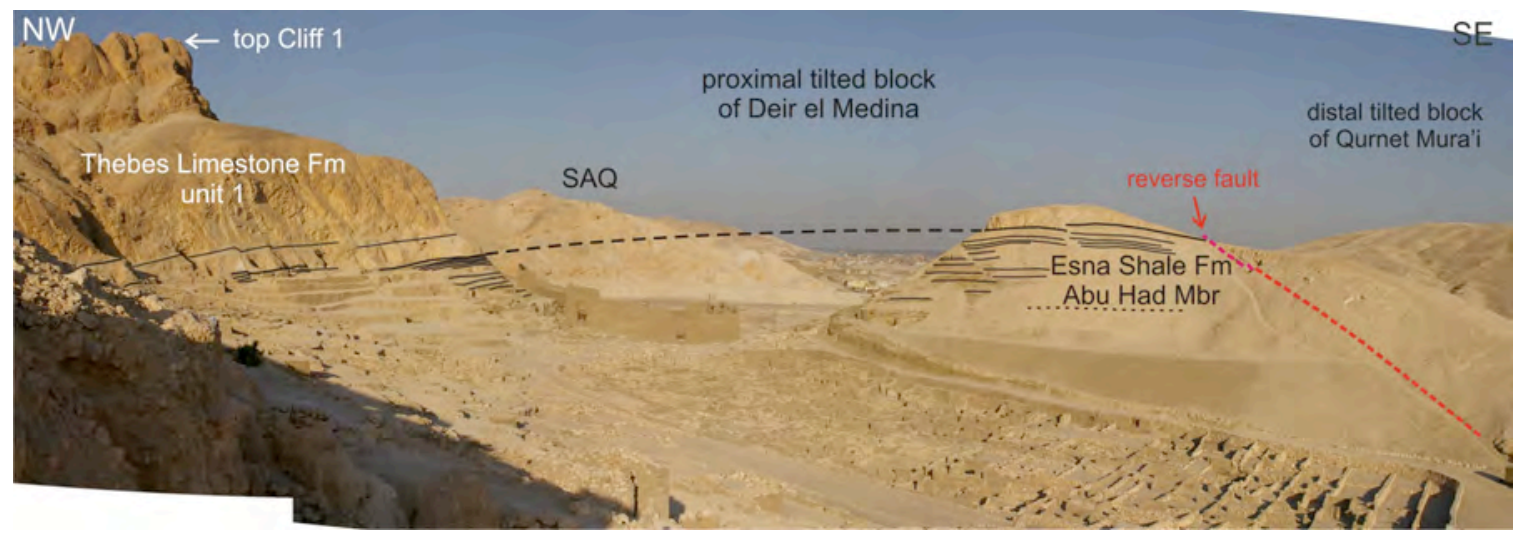

Figure 13. The Hills of Deir el Medina (left) and Qurnet Mura'î (right) as seen from the South, separated by the Valley of Deir el Medina with the ruins of the Village of the Workers occupied during the $18^{\text {th }}-20^{\text {th }}$ Dynasties and the Ptolemaic temple of the Hellenistic Period. Note the normal stratigraphic succession from the Abu Had Member of the Esna Shale Formation in the western hill of Qurnet Mura'î to the thick unit 1 of the Thebes Limestone Formation in the Hills of Deir el Medina. Note the eastern hill of Qurnet Mura'î to the extreme right, and the Hills of Sheikh Abd el Qurna (SAQ) in the background. 
$2 / 16 / 11$

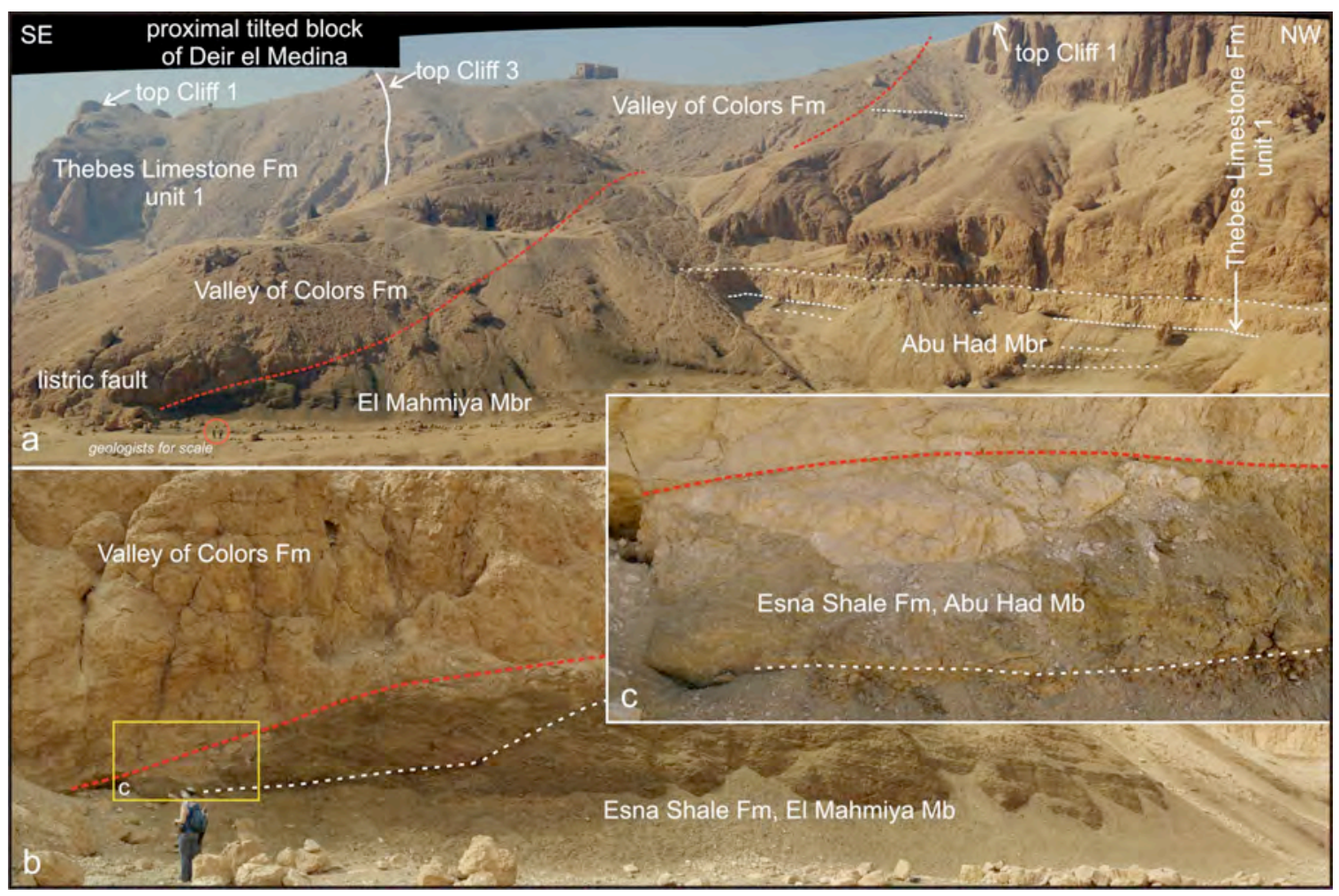

Figure 14. Listric fault at the contact between the tilted block of Deir el Medina and the substratum, as seen in the Valley of Colors. a. General view. b, c. Details of the above. 


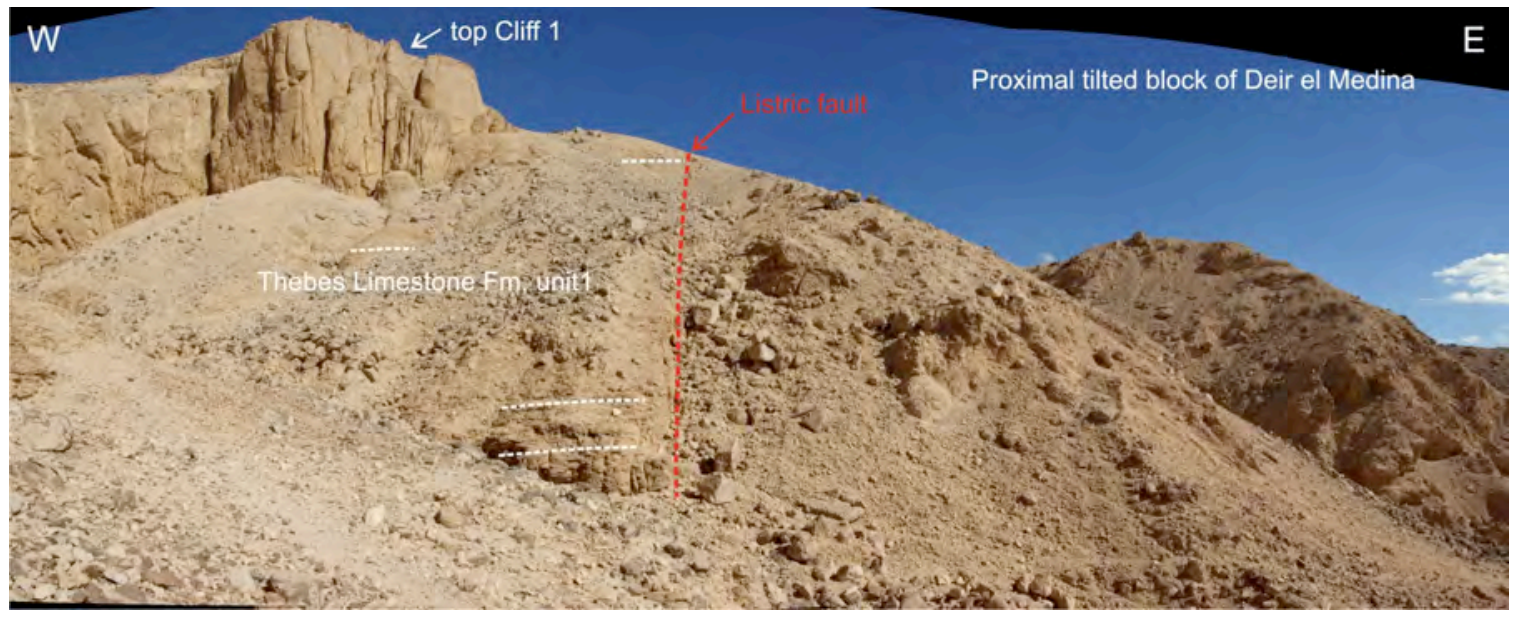

Figure 15. Fault contact between the in situ, horizontally stratified limestones of unit 1 of the Thebes Limestone formation in the Theban Plateau, and the proximal tilted block of Deir el Medina, as seen on the south flank of the block. 

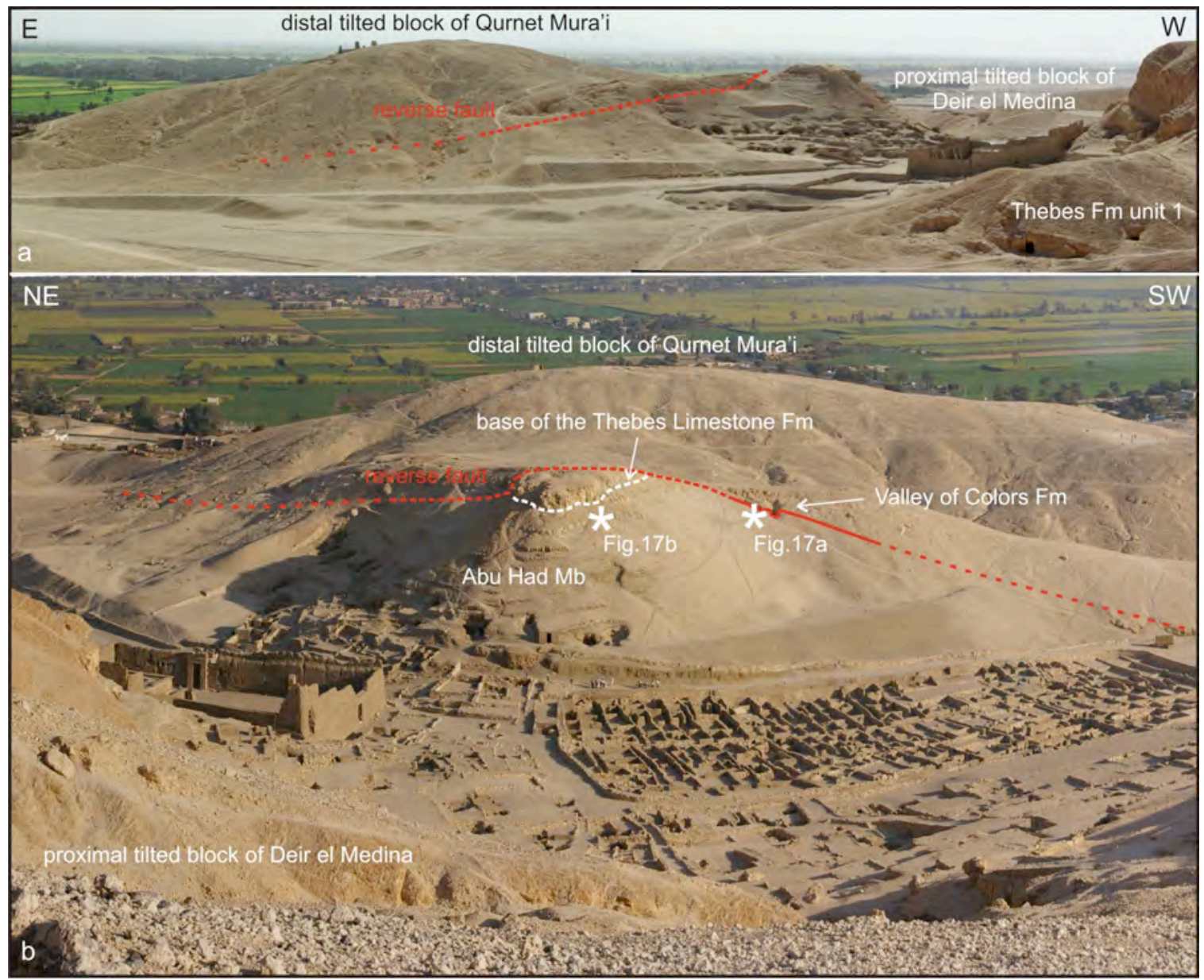

Figure 16. The Hills of Qurnet Mura'î. Note the contrast between the western hill with a young relief and clear stratigraphy, and the eastern hill with rounded top and obscure geology. a. View from the north. The cliff at the eastern end of the Hills of Deir el Medina is visible at the extreme right; $b$. View from the northwest. 


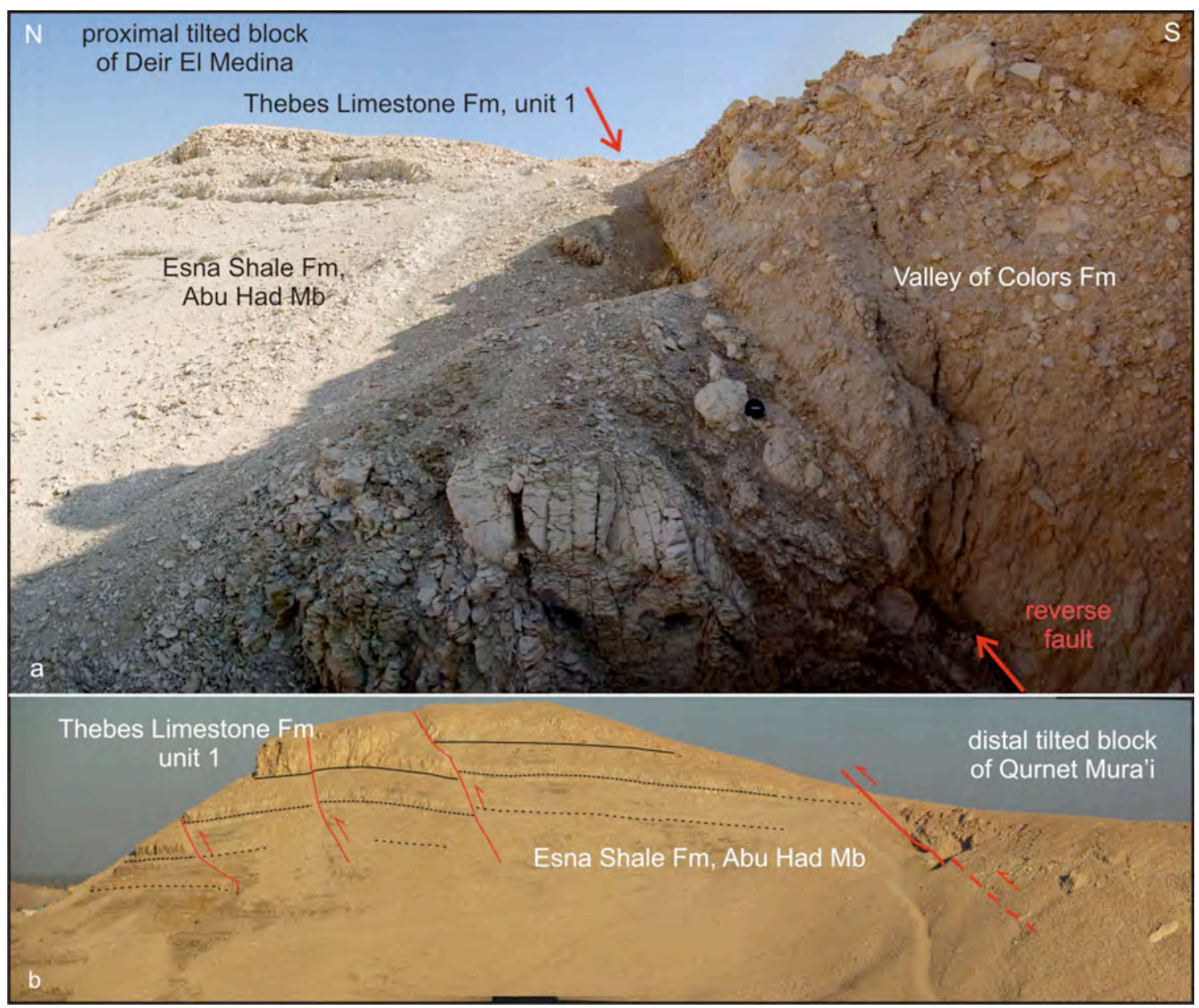

Figure 17. Reverse fault at the contact between the (proximal) tilted block of Deir El Medina and the distal block of Qurnet Mura'î, southern slope of the hills of Qurnet Mura'î.

a- The Esna Shale Formation of the proximal tilted block of Deir el Medina abuts against the Valley of Colors Formation of the (distal) tilted block of Qurnet Mura'î. Note the disrupted stratification in the Abu Had Member at the tectonic contact. (For location see star in Fig. 16a)

b- The Abu Had Member in the (proximal) TB of Deir el Medina: Note the regular stratification and the (three minor reverse) faults. A main reverse fault occurs at the contact between the two tilted blocks. (For location see star in Fig. 16b) 


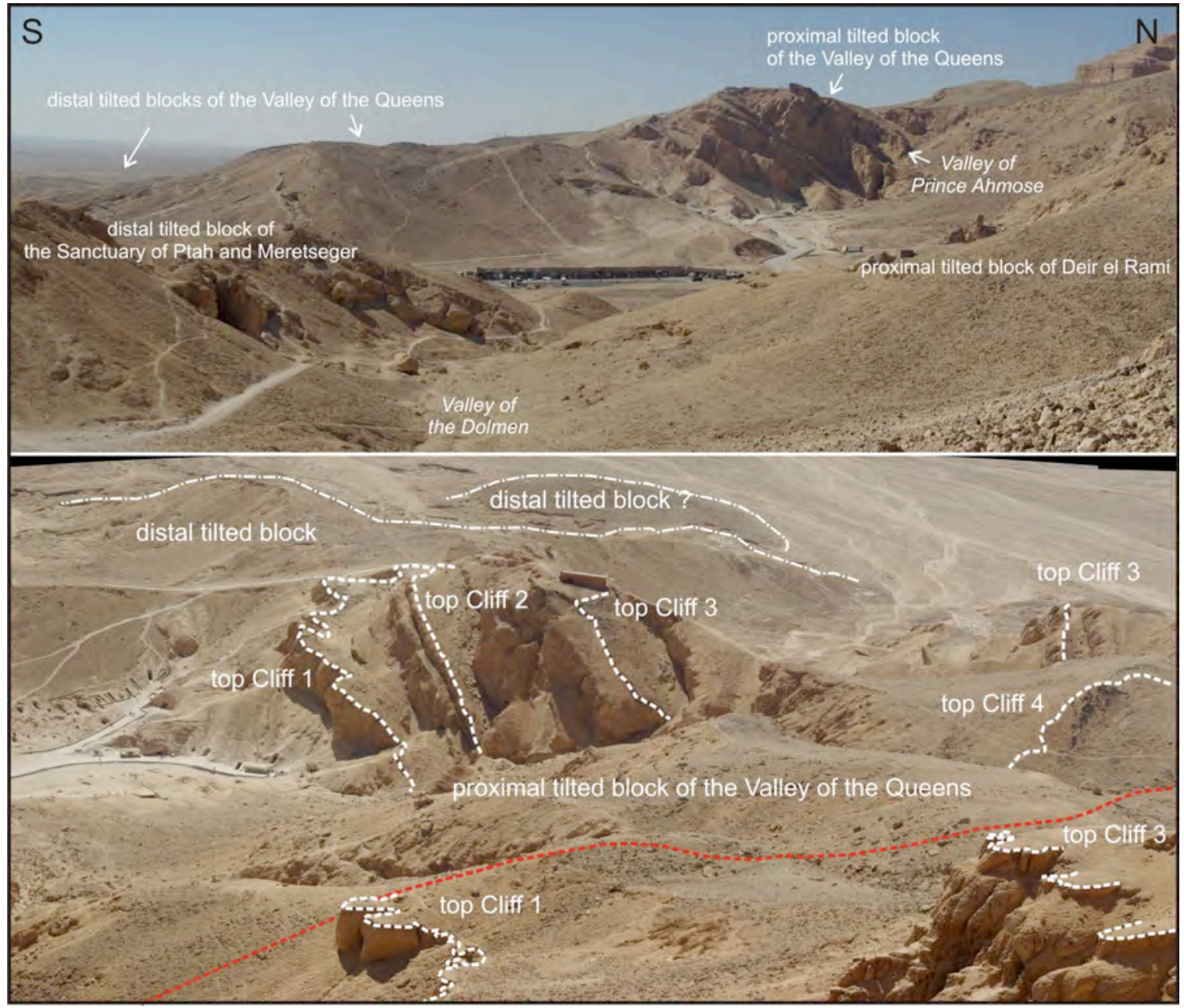

Figure 18. Theban hills south of the Hills of Deir el Medina.

a. The hills of the Sanctuary of Ptah and Meretseger along the Valley of the Dolmen, the Hills of Deir el Rami south of the Valley of the Three Wells, and the complex of tilted blocks of the Valley of the Queens. Note the contrast between the young relief and comprehensive stratigraphic exposures (complete succession through the Thebes Limestone Formation) in the east facing flank of the proximal tilted block of the Valley of the Queens (dominating the Valley of Prince Ahmose) and the subdued relief and lack of stratigraphic exposures elsewhere in the hills. Note also the Theban front (cliff 3 ) at the extreme right. The southernmost distal block extends beyond the limits of the topographic map (fig. 2).

b. Contact of the proximal Tilted Block of the Valley of the Queens with the Theban Cliffs, as seen from the Hills of Deir el Rami. Note that the tilted block comprises two promontories. These may be inherited from the morphology of the Theban Front prior to gravitational collapse, or may be the result of erosion subsequent to collapse. 


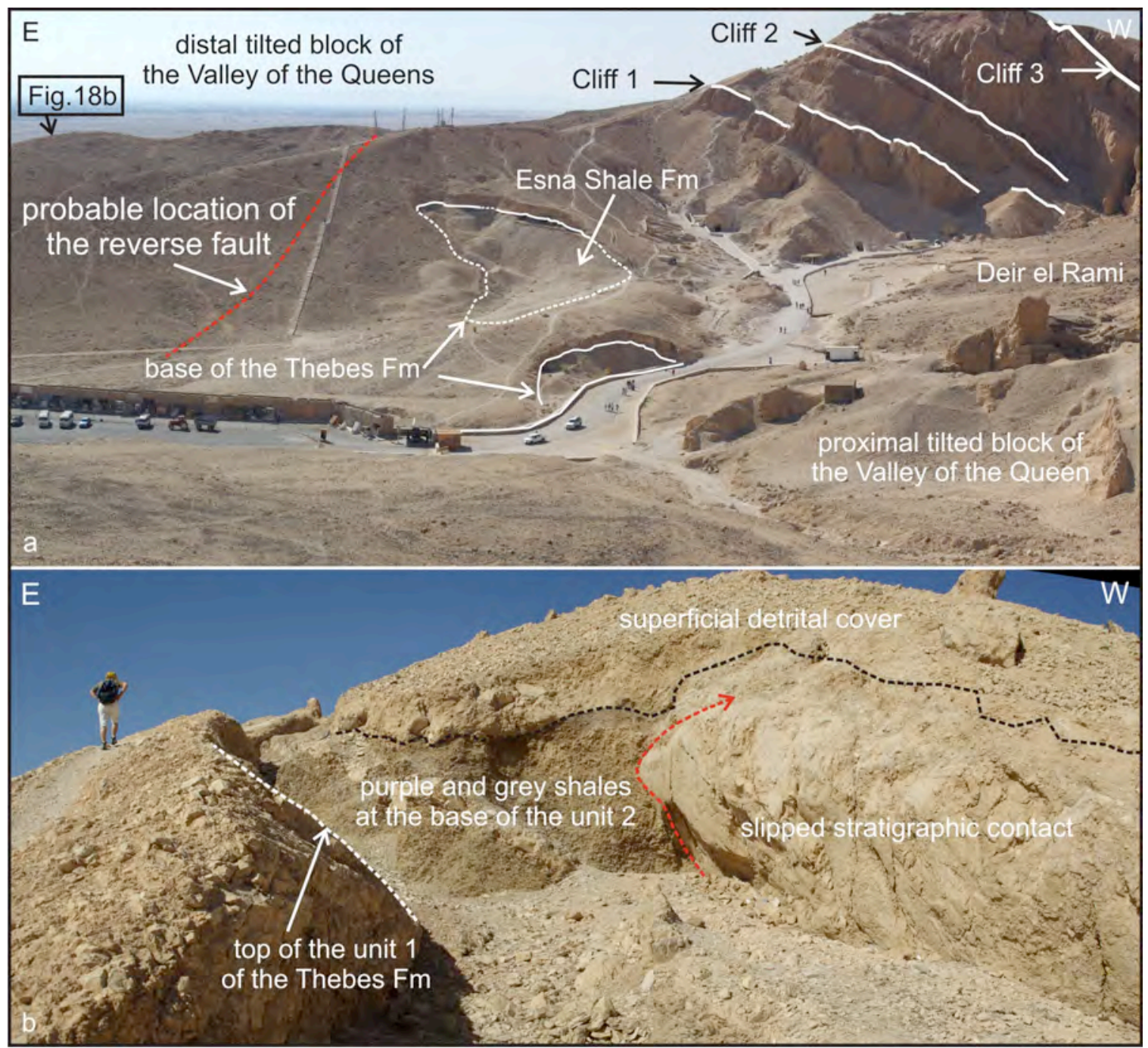

Figure 19. Distal and proximal tilted blocks of the Valley of the Queens.

a. Warping of the frontal beds of the proximal TB in the proximity of a distal TB.

b. Small quarry on the northeastern face of a distal TB in the Valley of the Queens. The bioturbated limestone of the upper part of unit 1 of the Thebes Limestone Formation is in contact with the shales of unit 2 along a fault, indicating strong deformation during the emplacement of the proximal tilted block, accompanied with tectonic thinning of the purple and grey shales of unit 2 . 
$2 / 16 / 11$

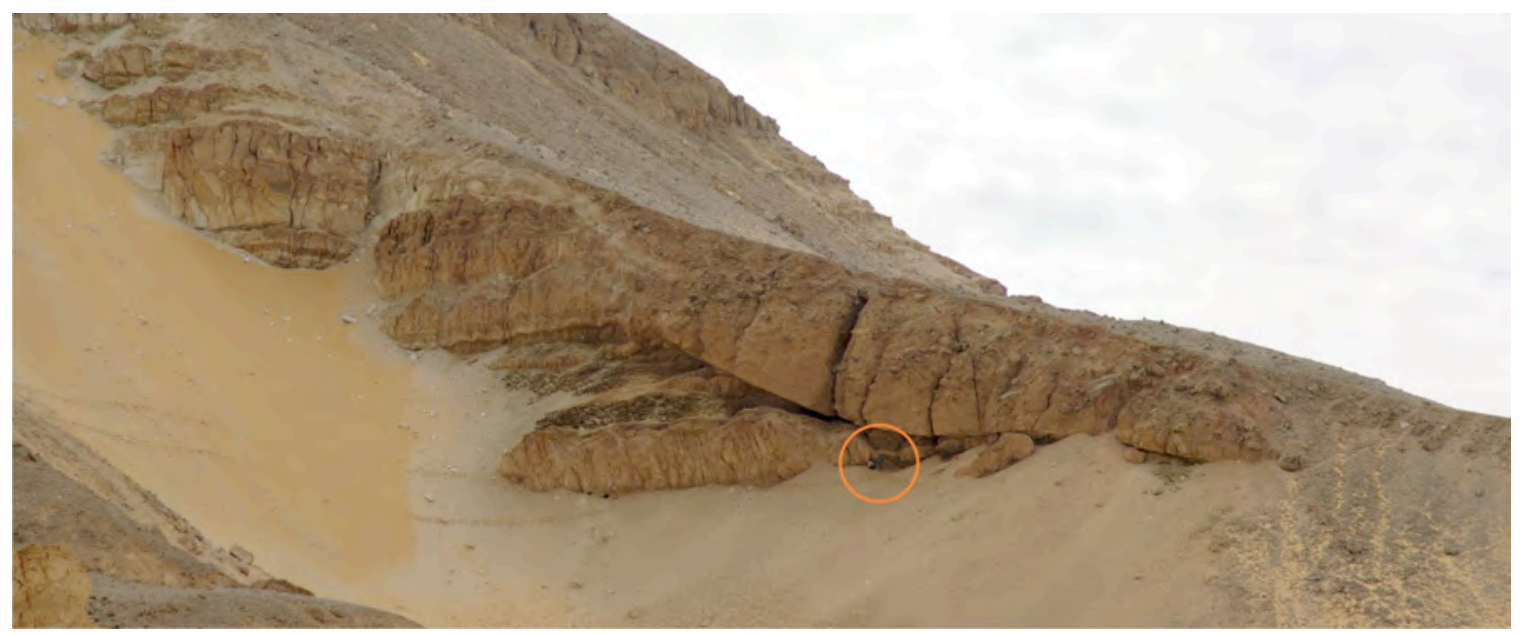

Figure 20. Indurated slope breccia at the front of the Saharan Plateau in Kharga Oasis. This constitutes a suitable genetic model for the Valley of Colors Formation. Note the two geologists (circle) standing at the foot of the breccia. 


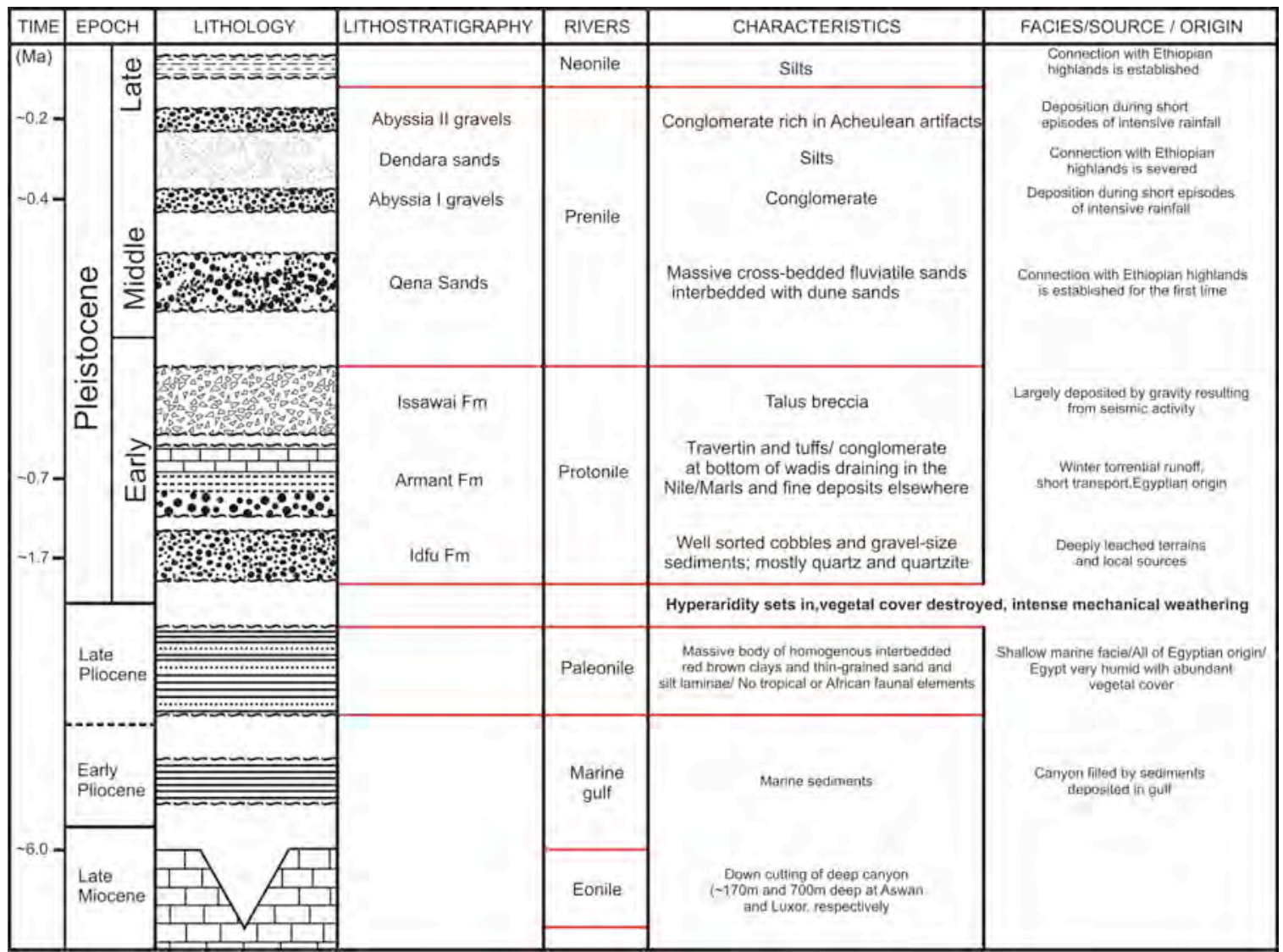

Figure 21. Sedimentary history along the Valley of the Nile in Egypt (after Said, 1981, 1990). The history of the modern Nile River began in the late Miocene (Messinian) when a river cut a vast canyon extending from Cairo to Aswan and beyond, thus delineating the future path of the Nile. Filled with marine sediments, the $1000 \mathrm{~km}$ long early Pliocene gulf became a river channel of which the late PliocenePleistocene history would be determined by the vagaries of tectonic activity and climatic changes (Said, 1981, 1990, 1993). Integrating lithologic, sedimentologic mineralogic and paleontologic characters of sedimentary successions in outcrops and wells along the current valley and delta, Said determined that five intermittent rivers replaced one another, fed by tributaries in Egypt alone or from sources deep in Sudan and/or Ethiopia. Note that the stratigraphic position of the Idfu Formation is given as below the Armant Formation in Said (1981) but above in Said (1990). 

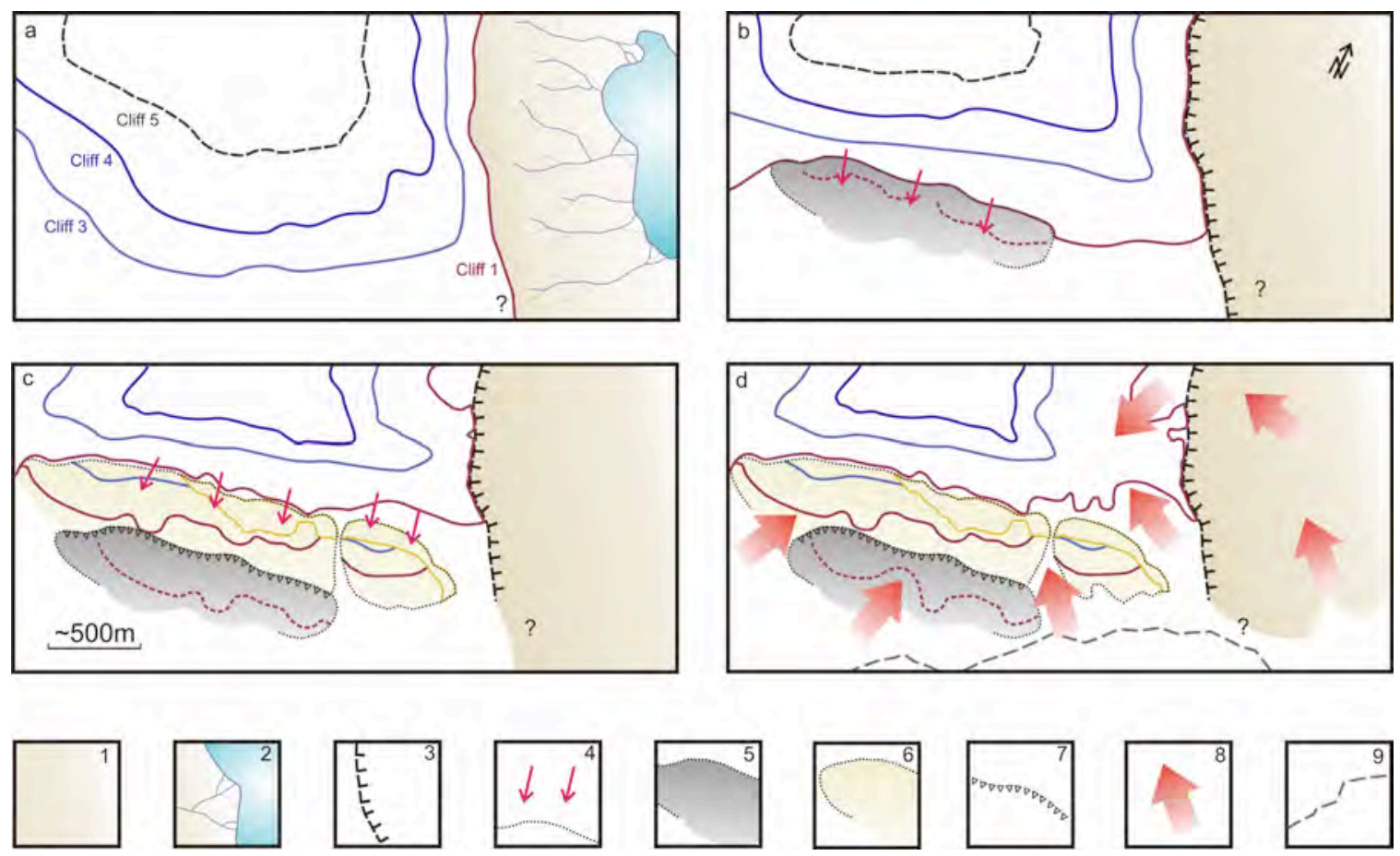

Figure 22. Post-Eocene history of the West Bank. a: Stage 1: Sedimentation in the Northern Basin prior to the genesis of the current Theban hills; the extension of the cliffs is based on Fig. 4; (b): Emplacement of the distal TBs; c: Emplacement of the proximal TBs; d. Erosion. (1): deposition of a detrital suite from gigantic breccias to silts and clays; (2) chemical deposition (evaporitic suite including dolomite, calcite and fibrous clays); (3) a paleocliff is locally exhumed, implying the erosion of the Theban front; (4) emplacement of the tilted blocks; (5) distal tilted block(s); (6): proximal tilted block(s); (7) reverse fault implying the collision of the proximal tilted block(s) with the adjacent distal tilted block(s), causing structural deformation. (8) erosional pattern subsequent to the emplacement of the proximal blocks. (9): Current limit of the flood plain. 
NW

Proximal tilted block of the Valley of the Queens

a

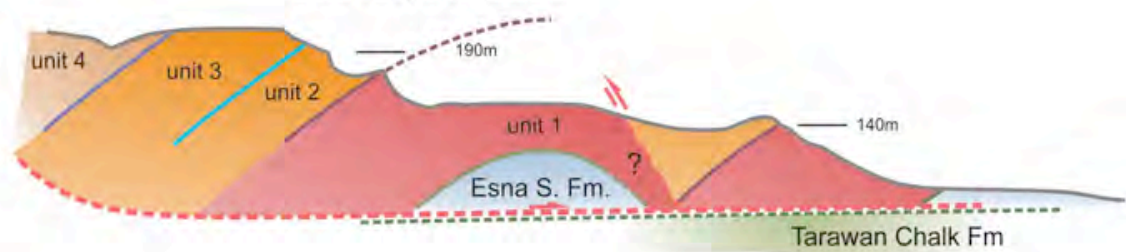

NW

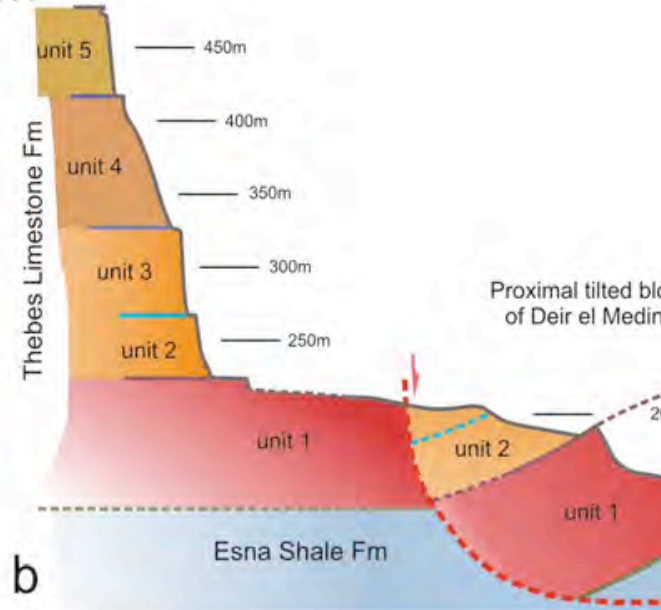

b

Esna Shale Fm
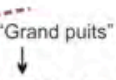

Temple of Deir el Medina

Distal tilted block of Qurnet Mura'i

SE

W

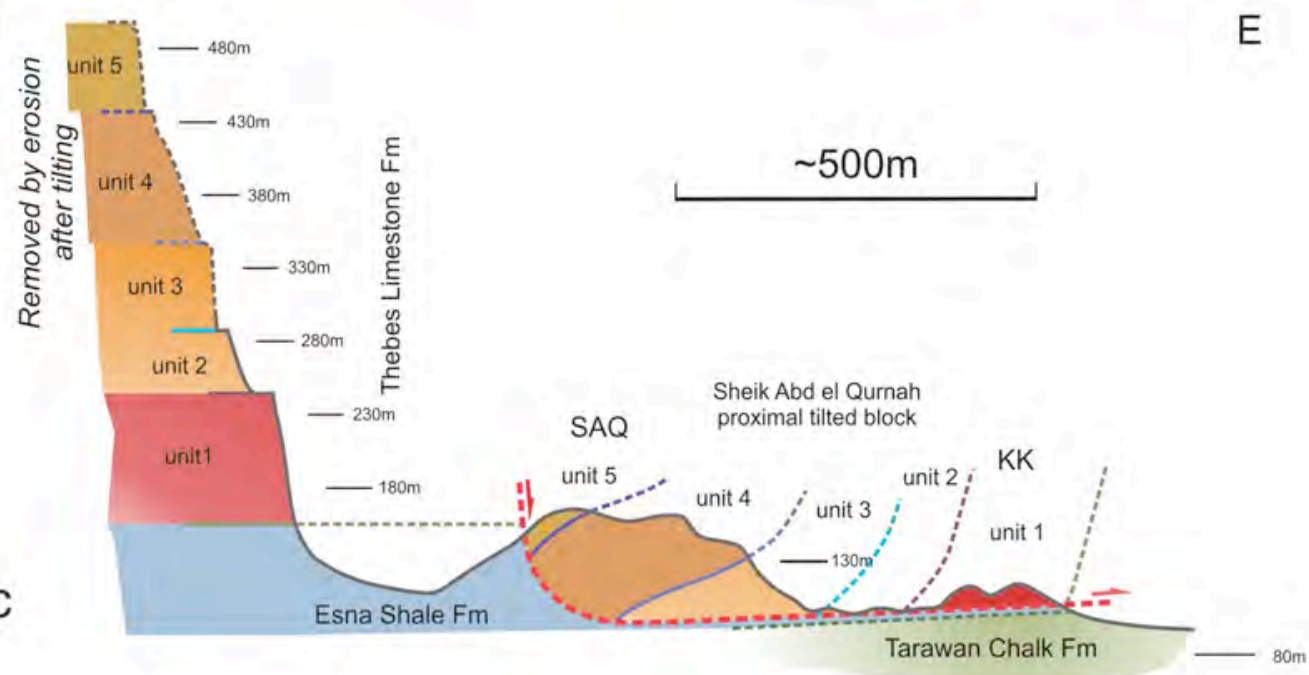


Figure 23. Structural transects along dip through the Theban hills.

(a): from the Theban Plateau to the flood plain through the tilted blocks of the Valley of the Queens

(b): from the Theban Plateau to the flood plain through the Hills of Deir el Medina and Qurnet Mura'î.

(c): from the Theban Plateau to the flood plain through the Hills of Sheikh Abd el Qurna and El Khokhah. Note: vertical exaggeration. 


\section{Appendix 1}

\section{The Valley of Color Formation: Definition}

Name: Valley of Colors Formation

Definition: Detrital deposit consisting of 1) massive, indurated, heterolithic and heterometric breccias with angular to subangular elements varying in size from millimetric to metric, and embedded in a coarse to fine calcareous to weakly clayey matrix, 2) unsorted, weakly to strongly stratified conglomerates and 3) well sorted arenites (Fig. 5)

Stratotype: Northwestern flank of the hills of Sheikh Abd el Qurna.

Upper boundary: The geometric relationships of this formation with the Armant Formation are unclear at this time

Lower boundary: The Valley of Colors Formation overlaps disconformably the Thebes Limestone Formation. The contact is mapped in Fig. 6.

Age: Probably post-Late Miocene when the Theban front formed as part of the down cutting of the Messinian Canyon by the Eonile (Said, 1981).

Geographic extent: outcrops forming a band from the northwestern flank of the hills of Sheikh Abd el Qurna and El Khokhah to the northwestern slopes in the hills of Deir el Medina. Excellent outcrops also occur in the southwestern face of the Hills of Deir el Medina. Outcrops also in the Hills of Qurnet Mura'î, et the contact between the proximal and distal tilted blocks. The Coptic Monastery of Tomb 1152 was built on the Valley of Colors Formation.

Stratigraphic relationships and genetic interpretation: As the listric contacts between the breccias and the substratum (Esna Shale and Tarawan Chalk) of the Theban Mountain show, the Valley of Colors Formation was formed prior to the emplacement of the tilted blocks by detachment from the Theban front and slumping. We interpret it as a slope deposit on the Thebes Limestone Formation, resulting from torrential activity possibly during a Pleistocene pluvial (Said, 1981, 1983; 1990).

Previous observations: The Valley of Colors Formation was reported (as "unnamed conglomerate") by Fronaberger (2002, p. 5) from Sheikh Abd el Qurna. His observations are essentially in agreement with our description, except for the statement that the conglomerate is everywhere poorly lithified and easily weathered. The cutting of tombs in the conglomerate plainly contradicts this. Fronaberger (2002) interpreted the conglomerate as a valley deposit near the flood plain of the Paleonile resulting from debris flows issued from the Theban cliffs. As we have shown above the Valley of Colors Formation is an integral part of the proximal TBs of Sheikh Abd el Qurna- El Khokhah and Deir el Medina, and also the 
$2 / 16 / 11$

distal TB of Qurnet Mura'î. It is best interpreted as a gravity-induced slope deposit resulting from thermic erosion and/or abundant runoff. It is possible that the Valley of Colors Formation is correlative with the Issawai Formation of Said $(1975,1981)$. 